\section{To: (Receiving organization) Distribution}

5. Proj./Prog./Dept./Div.:

Tank 241-AN-101/Waste

Management/DAI/TWRS

Technical Basis

8. Originator Remarks:

This document is being released into the supporting document system for retrievability purposes.

11. Receiver Remarks:

For release.
3. From: (Originating organization)

Data Assessment and Interpretation

6. cog. Engr.:

Cheryl J. Benar
4. Related EDT No.:

$N / A$

7. Purchase Order No.:

N/A

9. Equip./Component No.:

N/A

10:- System/8tdg./Facility:

241-AN-101

12. Major Assm. Dwg. Mo.:

$N / A$

13. Permit/Permit Application No.: $N / A$

14. Required Response Date: $07 / 22 / 96$

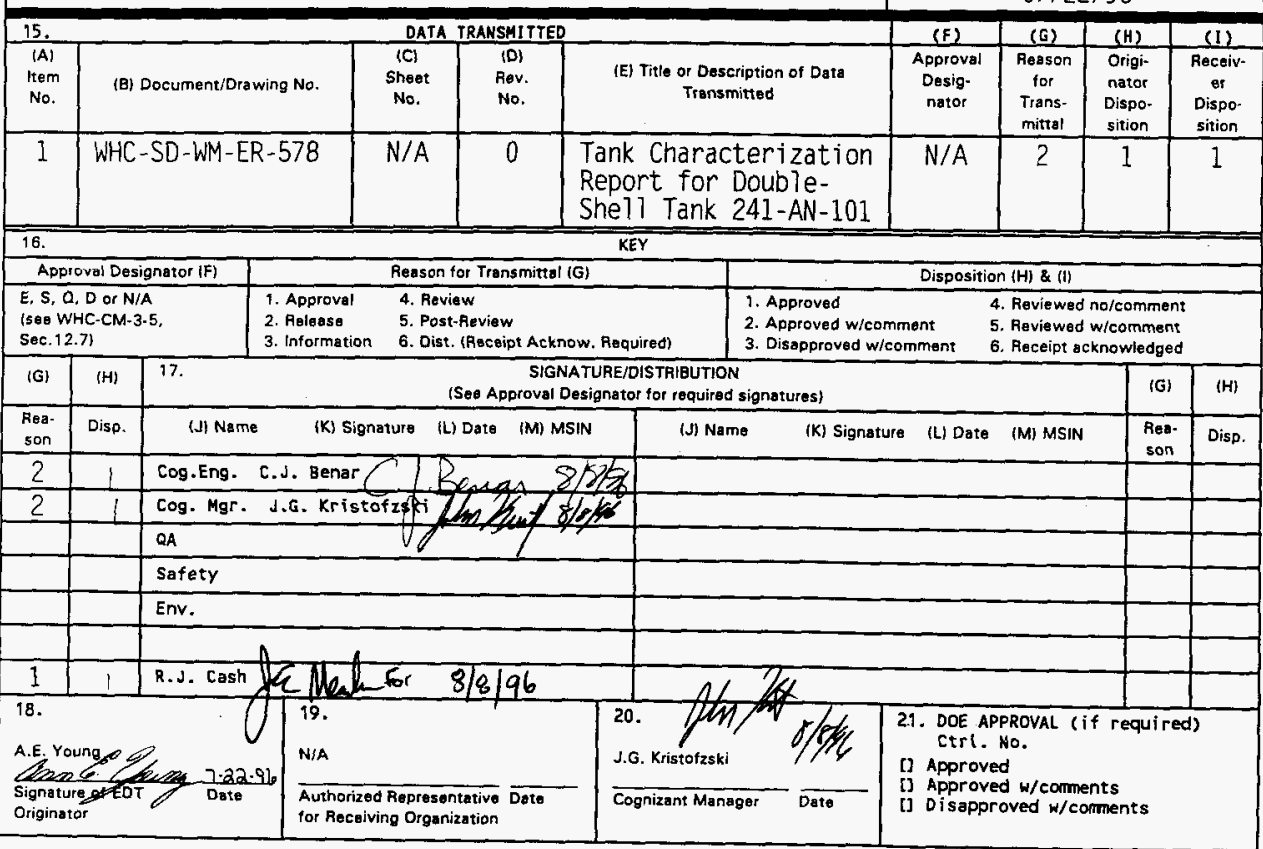

BD-7400-172-2 (04/94) GEF097 


\title{
Tank Characterization Report for Double-Shell Tank 241-AN-101
}

\author{
Cheryl J. Benar
}

Westinghouse Hanford Company. Richland. WA 99352

U.S. Department of Energy Contract DE-AC06-87RL10930

$\begin{array}{lll}\text { EDT/ECN: } & \text { EDT }-617505 & \text { UC: } 2070 \\ \text { Org Code: } & 79400 & \text { Charge Code: N4G4D } \\ \text { B\&R Code: } & \text { EW } 3120074 & \text { Total Pages: } 94\end{array}$

Key words: Tank Characterization Report, TCR, Double-She11 Tank. Double-She11. DST, Tank 241-AN-101. Tank AN-101. AN-101. AN Farm

Abstract: This document summarizes the information on the historical uses, present status, and the sampling and analysis results of waste stored in Tank 241-AN-101. This report supports the requirements of Tri-Party Agreement Milestone M-44-09.

TRADEMARK DISCLAIMER. Reference herein to any specific cormercial product, process, or service by trade name, trademark, manufacturer, or otherwise, does not necessarily constitute or imply its endorsement, recomendation, or favoring by the United States Goverment or any agency thereof or $i$ ts contractors or subcontractors.

Printed in the United States of America. To obtain copies of this document, contact: WHC/BCS Document Control Services, P.O. Box 1970, Mailstop H6-08, Richland WA 99352, Phone (509) 372-2420; Fax (509) 376-4989.
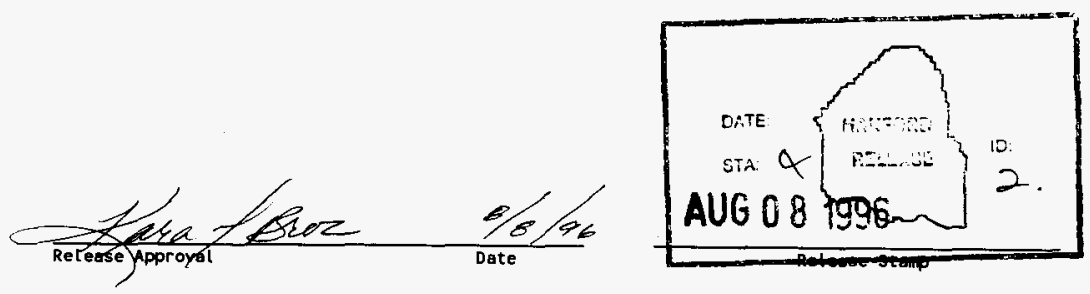

\section{Approved for Public Release}




\title{
Tank Characterization Report for Double-Shell Tank 241-AN-101
}

\author{
C. J. Benar \\ Westinghouse Hanford Company \\ L. C. Amato \\ Los Alamos Technical Associates \\ Date Published \\ August 1996
}

Prepared for the U.S. Department of Energy

Assistant Secretary for Environmental Management

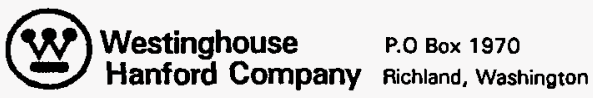

Management and Operations Contractor for the

U.S. Department of Energy under Contract DE-AC06-87RL10930

Approved for public release; distribution is unlimited 


\section{EXECUTTVE SUMMARY}

This tank characterization report summarizes information on the historical uses, current status, and sampling and analysis results of waste stored in double-shell underground storage tank 241-AN-101. This report supports the requirements of the Hanford Federal Facility Agreement and Consent Order, Milestone M-44-09 (Ecology et al. 1996).

Tank 241-AN-101 is one of seven double-shell tanks in the 200 East Area AN Tank Farm on the Hanford Site. The tank went into service in 1981, receiving PUREX low-level waste. In 1983, it began receiving saltwell liquid pumped from single-shell tanks. These transfers continued through October 1995 and have involved more than 30 single-shell tanks.

Periodically the waste in tank 241-AN-101 was sent to tank 241-AW-102 for concentration in the 242-A Evaporator. Other waste types received by tank 241-AN-101 include supernatant from tanks 241-AY-102, 241-AW-105, 241-AN-103, 241-AW-102; B Plant low-level waste; and concentrated phosphate waste from the $\mathrm{N}$ Reactor.

A description and the status of tank 241-AN-101 are summarized in Figure ES-1 and Table ES-1. The tank has an approximate capacity of 4,390 kL (1,160 kgal) and contains $4,090 \mathrm{~kL}(1,080 \mathrm{kgal})$ of dilute noncomplexed waste, composed entirely of supernatant (Hanlon 1996). Tank 241-AN-101 is an active tank, so the waste volumes in Figure ES-1 and Table ES-1 may not represent the current tank contents. 
Figure ES-1. Profile of Tank 241-AN-101.
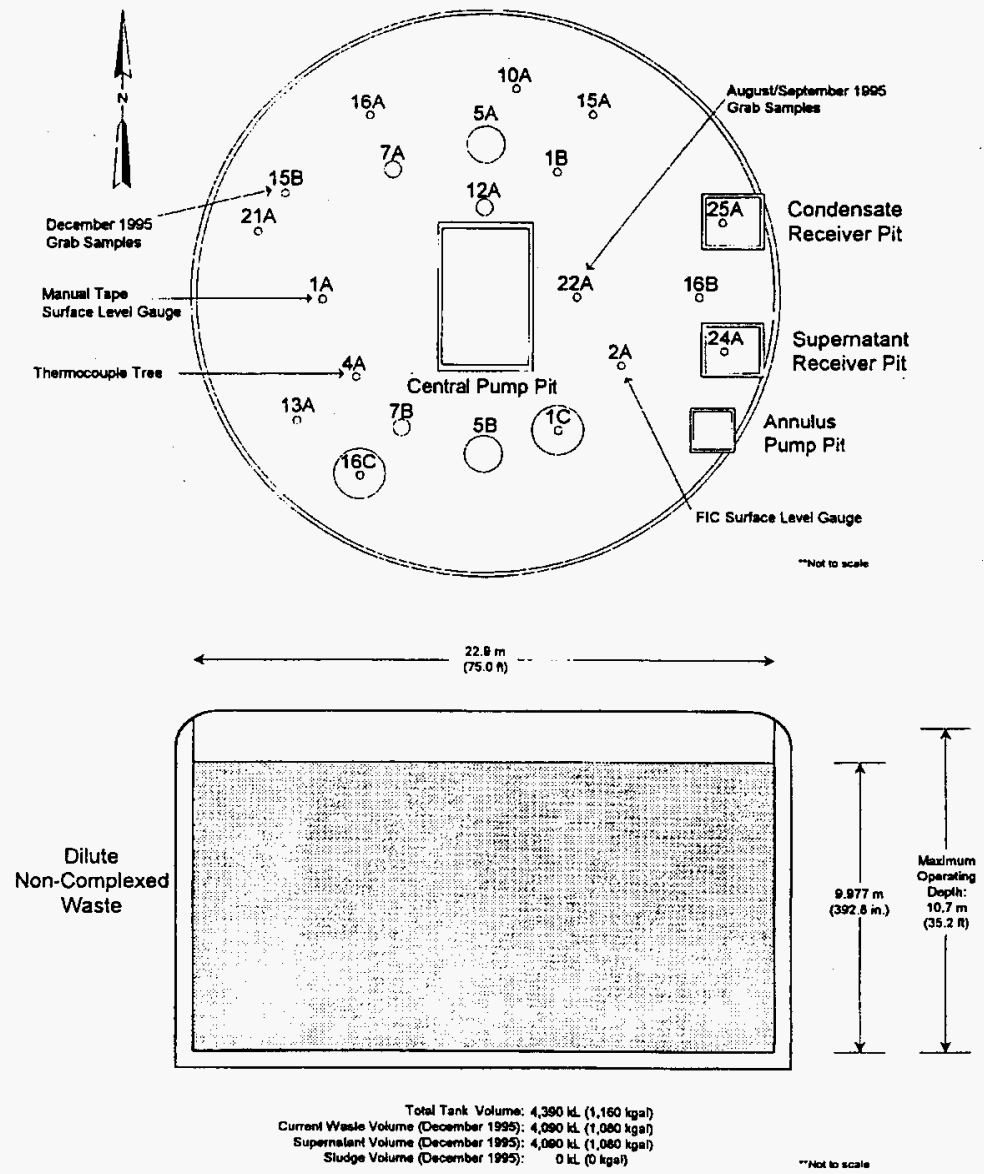
Table ES-1. Description and Status of Tank 241-AN-101.

\begin{tabular}{|c|c|}
\hline (1) TWR & MMON \\
\hline Type & $\begin{array}{ll}\text { Double-shell } & \\
\end{array}$ \\
\hline Constructed & $1980-81$ \\
\hline In service & 1981 \\
\hline Diameter & $22.9 \mathrm{~m}(75.0 \mathrm{ft})$ \\
\hline Maximum operating depth & $10.7 \mathrm{~m}(35.2 \mathrm{ft})$ \\
\hline Capacity & $4,390 \mathrm{~kL}(1,160 \mathrm{kgal})$ \\
\hline Bottom shape & Flat \\
\hline Ventilation & Active \\
\hline 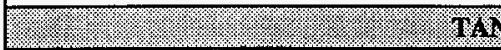 & X: \\
\hline Waste classification & Dilute noncomplexed \\
\hline Total waste volume (December 1995) & $4,090 \mathrm{~kL}(1,080 \mathrm{kgal})$ \\
\hline Supernatant volume (December 1995) & $4,090 \mathrm{~kL}(1,080 \mathrm{kgal})$ \\
\hline Sludge volume (December 1995) & $0 \mathrm{~kL}(0 \mathrm{kgal})$ \\
\hline Waste surface level (March 21, 1996) & $9.98 \mathrm{~m}(392.8 \mathrm{in})$. \\
\hline Temperature (July 1983 to March 1996) & 32.4 to $11^{\circ} \mathrm{C}\left(90.3\right.$ to $\left.52^{\circ} \mathrm{F}\right)$ \\
\hline Integrity & Sound \\
\hline Watch List & None \\
\hline l: SAMP & GWTS \\
\hline Grab samples & August/September 1995, December 1995 \\
\hline SERV & MTUS \\
\hline In service & \\
\hline
\end{tabular}

The characterization of tank 241-AN-101 is based on two 1995 grab sampling events, one in August/September and the other in December. The August/September sampling event was performed to satisfy the requirements of the Data Quality Objectives for the Waste Compatibility Program (Fowler 1995). Three grab samples were obtained from riser 22A. The sampling and analyses were performed in accordance with the Compatibility Grab Sampling and Analysis Plan (Jones 1995) with the following exception. Jones (1995) cites 
revision 0 of the waste compatibility data quality objective (DQO) as the applicable DQO. However, the samples were analyzed against Fowler (1995) because it was the most recent revision (revision 1 ) of the waste compatibility DQO. As required by the waste compatibility DQO, analyses for energetics, moisture content, total organic carbon (TOC), total inorganic carbon (TIC), selected metals, anions, selected radionuclides, $\mathrm{pH}$, and specific gravity were performed on the grab samples, along with a visual check for the presence of an organic layer.

A decision was made later to conduct a safety screening assessment on the tank according to Tank Safety Screening Data Quality Objective (Dukelow et al. 1995). Because the DQO requires a vertical profile of waste from two risers, three grab samples were taken from riser 15B in December 1995. The results were to be used in conjunction with the results from the August/December 1995 sampling event, which were from a different riser.

As prescribed by the safety screening DQO, the grab samples were checked for the presence of an organic layer and analyzed for energetics, moisture content, total alpha activity, and specific gravity. The total alpha activity analyses were not required by the waste compatibility DQO, so it was necessary to perform these analyses on archived samples from the August/September 1995 sampling event. Prior to removal of the grab samples, the tank vapors were field tested using a combustible gas meter. 
After the December 1995 sampling event, it was discovered that in September and October 1995, tank AN-101 received waste from saltwell liquid pumping and an unknown source. Because the tank contents changed during the time between sampling events, only the December 1995 results were used to complete the safety screening evaluation. An additional . sampling event may be necessary to complete a safety screening assessment while satisfying the safety screening $D Q O$ requirement of obtaining samples from two risers.

Comparisons were made between the analytical results and the notification limits of the safety screening DQO. No exothermic reactions were observed for any samples. The average weight percent water value by thermogravimetric analysis (TGA) was 65.4 weight percent. The overall total alpha activity mean was $<0.00147 \mu \mathrm{Ci} / \mathrm{mL}$, which was far below the notification limit. The concentration of the tank headspace gases was 0 percent of the lower explosive limit (LEL), which more than satisfied the safety screening requirement.

Comparisons also were made between the analytical results and the safety and operational limits identified in the waste compatibility DQO. The safety issues of the DQO include energetics, criticality, flammable gas accumulation, and corrosion. All analytical results satisfied their respective safety criteria. In addition, all the operational limits evaluated were satisfied; the transuranic (TRU) content, and heat load were below levels which would cause the waste to be segregated. 
The tank heat load, based on radionuclide analytical data, was $2,380 \mathrm{~W}(8,120 \mathrm{Btu} / \mathrm{hr})$, much lower than the $20,500 \mathrm{~W}(70,000 \mathrm{Btu} / \mathrm{hr})$ operating specification limit. The historical tank content estimate (HTCE) prediction for heat load was $102 \mathrm{~W}$ (349 Btu/hr) (Brevick et al. 1995a). The average tank temperature between July 1983 and March 1996 was $22.1^{\circ} \mathrm{C}$ $\left(71.8^{\circ} \mathrm{F}\right)$, with a minimum of $11^{\circ} \mathrm{C}\left(52{ }^{\circ} \mathrm{F}\right)$ and a maximum of $32.4^{\circ} \mathrm{C}\left(90.3^{\circ} \mathrm{F}\right)$.

March 21, 1996 surveillance data show a waste level of $9.977 \mathrm{~m}(32.73 \mathrm{ft})$.

Table ES-2 provides concentration and inventory estimates for the most prevalent analytes and analytes of concern. The sample results used for this table are from the August/September 1995 sampling event. Since that time, waste transactions have occurred and the table is no longer representative of the tank contents.

Table ES-2. Major Analytes and Analytes of Concern for Tank 241-AN-101. ${ }^{1}$ (2 sheets)

\begin{tabular}{|c|c|c|c|}
\hline Analyes & $\begin{array}{l}\text { Oremal Wherit } \\
\text { Concentration }\end{array}$ & 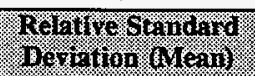 & 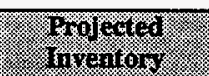 \\
\hline METALS: & $8 g / \mathrm{mi}$ & l. & (3) \\
\hline Aluminum & 20,900 & 3.5 & 85,500 \\
\hline Sodium & $1.28 \mathrm{E}+05$ & 3.0 & $5.24 \mathrm{E}+05$ \\
\hline ANONS & rgini & (2) & (20\% \\
\hline Chloride & 3,300 & 1.0 & 13,500 \\
\hline Hydroxide & 31,400 & 2.5 & $1.28 \mathrm{E}+05$ \\
\hline Nitrate & 97,100 & 1.8 & $3.97 \mathrm{E}+05$ \\
\hline Nitrite & 48,200 & 2.7 & $1.97 \mathrm{E}+05$ \\
\hline Phosphate & 2,120 & 19.2 & 8,670 \\
\hline Sulfate & 3,040 & 24.5 & 12,400 \\
\hline PHOTONUCMIOES & ICHmi: & \% & (1) \\
\hline${ }^{137} \mathrm{Cs}$ & 123 & 0.6 & $5.03 \mathrm{E}+05$ \\
\hline${ }^{90} \mathrm{Sr}$ & 0.378 & 28.3 & 1,550 \\
\hline Total alpha & $<0.00059$ & --- & $<2.41$ \\
\hline
\end{tabular}


Table ES-2. Major Analytes and Analytes of Concern

for Tank 241-AN-101. ${ }^{1}$ (2 sheets)

\begin{tabular}{|c|c|c|c|}
\hline Amprite & Orentimirern & 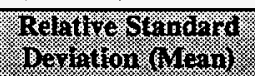 & Projected \\
\hline GraOH & $2.34 \mathrm{mi}$ & (1: & 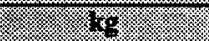 \\
\hline Total inorganic carbon & 2,450 & 2.7 & 10,000 \\
\hline Total organic carbon & $2,630(7,670)^{2}$ & 18.0 & 10,800 \\
\hline \multicolumn{4}{|c|}{ 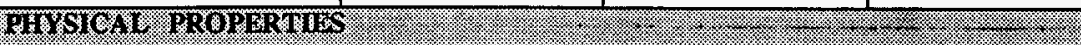 } \\
\hline $\mathrm{pH}$ & 13.6 & $2.3 \%+\cdot$ & $\cdots$ \\
\hline Water & $66.0 \mathrm{wt} \%$ & 0.5 wt \% & $2.70 \mathrm{E}+06$ \\
\hline Specific gravity & 1.23 & $1.0 \%$ & -- \\
\hline
\end{tabular}

Notes:

'Esch (1995 and 1996)

${ }^{2}$ Value in parentheses is the TOC dry weight result. 
WHC-SD-WM-ER-578 Rev. 0

This page intentionally left blank. 


\section{CONTENTS}

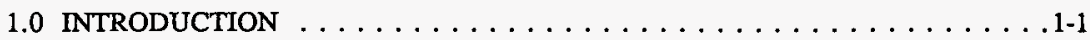

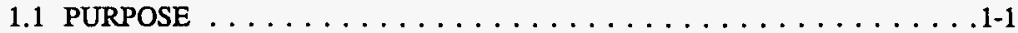

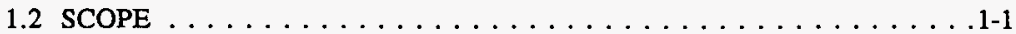

2.0 HISTORICAL TANK INFORMATION $\ldots \ldots \ldots \ldots \ldots \ldots \ldots \ldots \ldots . \ldots \ldots$

2.1 TANK STATUS $\ldots \ldots \ldots \ldots \ldots \ldots \ldots \ldots \ldots \ldots \ldots \ldots \ldots \ldots .2-1$

2.2 TANK DESIGN AND BACKGROUND $\ldots \ldots \ldots \ldots \ldots \ldots \ldots .2-2$

2.3 PROCESS KNOWLEDGE $\ldots \ldots \ldots \ldots \ldots \ldots \ldots \ldots \ldots \ldots \ldots$

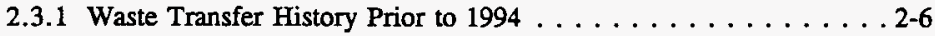

2.3.2 Waste Transfer History After January $1,1994 \ldots \ldots \ldots \ldots . .28$

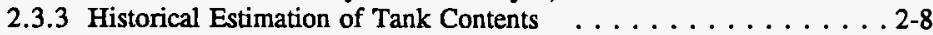

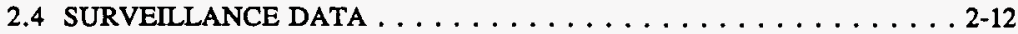

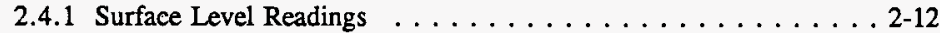

2.4.2 Internal Tank Temperatures $\ldots \ldots \ldots \ldots \ldots \ldots \ldots \ldots \ldots .12$

2.4.3 Tank 241-AN-101 Photograph . . . . . . . . . . 2-12

3.0 TANK SAMPLING OVERVIEW . . . . . . . . . . . . . . . 3-1

3.1 DESCRIPTION OF SAMPLING EVENTS $\ldots \ldots \ldots \ldots \ldots \ldots \ldots$.1

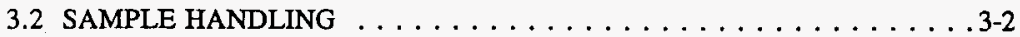

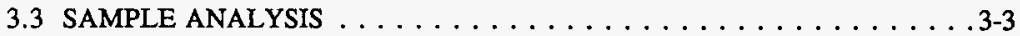

3.3.1 Thermal Analysis - Thermogravimetric Analysis and Differential Scanning Calorimetry . . . . . . . . . . 3-4

3.3.2 Total Alpha Activity Analysis . . . . . . . . . . . . . 3-4

3.3.3 Specific Gravity . . . . . . . . . . . . . . . . 6

3.3.4 Gamma Energy Analysis . . . . . . . . . . . . . . 3-6

3.3.5 Inductively Coupled Plasma/

Atomic Emission Spectroscopy . . . . . . . . . . 3-6

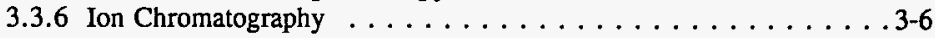

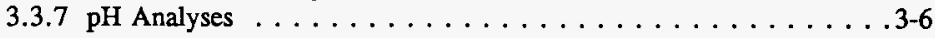

3.3.8 Hydroxide Ion Titration . . . . . . . . . . . . . . 3-6

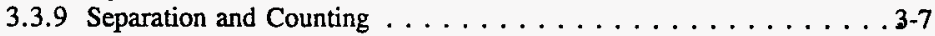

3.3 .10 Total Carbon . . . . . . . . . . . . . . . .

3.3.11 Visual Check and Over-the-Top

Radiation Measurements . . . . . . . . . . . . . 3-7

3.3.12 Percent Solids . . . . . . . . . . . . . . . . . .3-7

3.4 HISTORICAL SAMPLING EVENTS $\ldots \ldots \ldots \ldots \ldots \ldots \ldots \ldots \ldots$

4.0 ANALYTICAL RESULTS $\ldots \ldots \ldots \ldots \ldots \ldots \ldots \ldots \ldots \ldots \ldots$. . . . . . . . . .

4.1 DATA PRESENTATION . . . . . . . . . . . . . . . 4-1

4.1 .1 Chemical Data Summary . . . . . . . . . . . . 4-2

4.1.2 Physical Data Summary . . . . . . . . . . . . . . 4-3

4.1.3 Headspace Flammability Screening Results . . . . . . . . . 4-5 


\section{CONTENTS (Continued)}

5.0 INTERPRETATION OF CHARACTERIZATION RESULTS $\ldots \ldots \ldots \ldots \ldots$ 5-1

5.1 ASSESSMENT OF SAMPLING AND ANALYTICAL RESULTS $\ldots \ldots$ 5-1

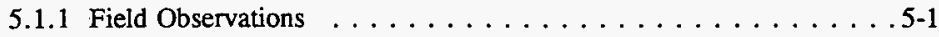

5.1 .2 Quality Control Assessment ............... 5-1

5.1.3 Data Consistency Checks . . . . . . . . . . . . . 5-2

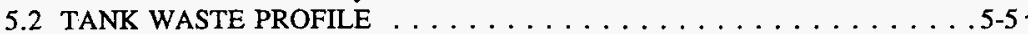

5.3 EVALUATION OF PROGRAM REQUIREMENTS $\ldots \ldots \ldots \ldots \ldots$ 5-6

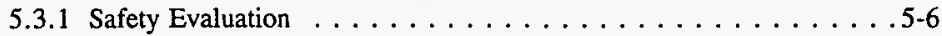

5.3.2 Operations Decision Rules Evaluation . . . . . . . . . . 5-9

6.0 CONCLUSIONS AND RECOMMENDATIONS $\ldots \ldots \ldots \ldots \ldots \ldots$ 6-1

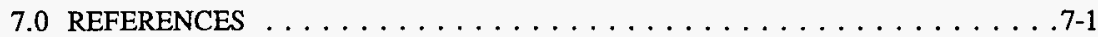

APPENDICES

A ANALYTICAL RESULTS FROM 1995 GRAB SAMPLING EVENTS . . . . . A A-1

B HISTORICAL SAMPLING RESULTS $\ldots \ldots \ldots \ldots \ldots \ldots$ B-1 


\section{LIST OF FIGURES}

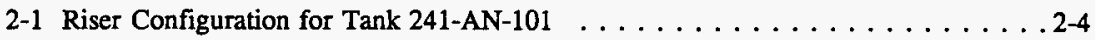

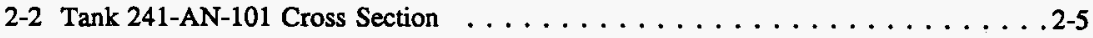

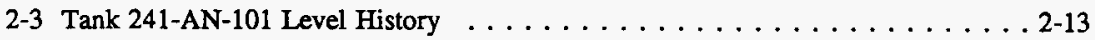

2-4 Tank 241-AN-101 Weekly High Temperature Plot . . . . . . . . . . . . . . 2-14

\section{LIST OF TABLES}

2-1 Estimated Tank Contents $\ldots \ldots \ldots \ldots \ldots \ldots \ldots \ldots \ldots \ldots \ldots$ 2-1

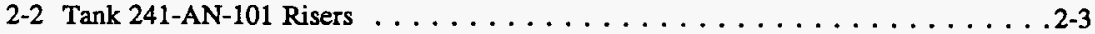

2-3 Summary of Incoming Waste Transfer History Prior to $1994 \ldots \ldots$. . . . . . 2-7

2-4 Summary of Waste Transfer History After January $1,1994 \ldots \ldots$. . . . . . . . 2-9

2-5 Double-Shell Tank 241-AN-101 Historical Inventory Estimate $\ldots \ldots \ldots \ldots$ 2-10

3-1 Integrated Data Quality Objective Requirements for Tank 241-AN-101 . . . . . . 3-2

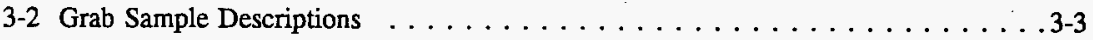

3-3 Tank 241-AN-101 Sample Analysis Summary $\ldots \ldots \ldots \ldots$. . . . . . . . .

3-4 Analytical Procedures $\ldots \ldots \ldots \ldots \ldots \ldots \ldots \ldots \ldots \ldots \ldots . . \ldots \ldots$

4-1 Analytical Data Presentation Tables . . . . . . . . . . . . . 4-1

4-2 Chemical Data Summary for Tank $241-A N-101 \ldots \ldots \ldots$. . . . . . . . . .

4-3 Thermogravimetric Analysis Results for Tank 241-AN-101 . . . . . . . . 4-5

4-4 Differential Scanning Calorimetry Results for Tank 241-AN-101 . . . . . . . . 4-6

4-5 Headspace Flammability Screening for Tank 241-AN-101 . . . . . . . . 4-7 


\section{LIST OF TABLES (Continued)}

5-1 Comparison of the Total Alpha Activity with the Sum of the Individual Activities . . . . . . . . . . . . . . . . . . 2

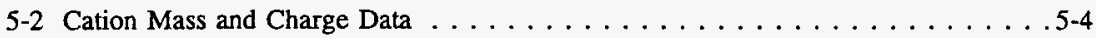

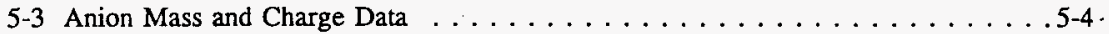

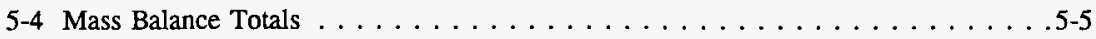

5-5 Decision Variables and Criteria for the Safety Screening Data Quality Objective . . 5-8

5-6 Decision Variables and Criteria for the Waste Compatibility Data Quality Objective . . . . . . . . . . . . . . . . . .

5-7 Tank 241-AN-101 Projected Heat Load . . . . . . . . . . . . . . . . . 5-9

5-8 Waste Compatibility Operations Decision Rules . . . . . . . . . . . . 5-10 


\section{LIST OF TERMS}

$\begin{array}{ll}\text { ANOVA } & \text { analysis of variance } \\ \text { Btu/hr } & \text { British thermal units per hour } \\ \text { Ci } & \text { curies } \\ \text { Ci/g } & \text { curies per gram } \\ \text { Ci/L } & \text { curies per liter } \\ \text { cm } & \text { centimeters } \\ \text { DBP } & \text { Dibutyl phosphate } \\ \text { DQO } & \text { data quality objective } \\ \text { DSC } & \text { differential scanning calorimetry } \\ \text { EDTA } & \text { Ethylenediaminetetraacetic acid } \\ \text { FIC } & \text { Food Instrument Corporation } \\ \text { ft } & \text { feet } \\ \text { g/gal } & \text { grams per gallon } \\ \text { g/L } & \text { grams per liter } \\ \text { g/mL } & \text { grams per milliliter } \\ \text { GEA } & \text { gamma energy analysis } \\ \text { HDW } & \text { Hanford Defined Waste } \\ \text { HEDTA } & \text { N-hydroxyethylenediaminetriacetic acid } \\ \text { HTCE } & \text { Historical Tank Content Estimate } \\ \text { IC } & \text { ion chromatography } \\ \text { ICP } & \text { inductively coupled plasma spectroscopy } \\ \text { ID } & \text { identification } \\ \text { in. } & \text { inches } \\ \text { J/g } & \text { joules per gram } \\ \text { kg } & \text { kilograms } \\ \text { kgal } & \text { kilogallons } \\ \text { kL } & \text { kiloliters } \\ \text { LEL } & \text { lower explosive limit } \\ \text { LFL } & \text { lower flammability limit } \\ \text { m } & \text { meters } \\ \text { M } & \text { moles per liter } \\ \text { mg } & \text { milligrams } \\ \text { mL } & \text { milliliters } \\ \text { mrad/hr } & \text { millirads per hour } \\ \text { ppm } & \text { parts per million } \\ \text { PUREX } & \text { plutonium-uranium extraction } \\ \text { RPD } & \text { relative percent difference } \\ \text { RSD } & \text { relative standard deviation } \\ \text { SAP } & \text { sampling and analysis plan } \\ \text { SpG } & \text { specific gravity } \\ \text { TGA } & \text { thermogravimetric analysis } \\ \text { TIC } & \text { total inorganic carbon } \\ & \\ & \end{array}$




\section{LIST OF TERMS (Continued)}

$\begin{array}{ll}\text { TLM } & \text { Tank Layer Model } \\ \text { TOC } & \text { total organic carbon } \\ \text { TRU } & \text { transuranics } \\ W & \text { watts } \\ \text { WSTRS } & \text { Waste Status and Transaction Record Summary } \\ w t \% & \text { weight percent } \\ { }^{\circ} \mathrm{C} & \text { degrees Celsius } \\ { }^{\circ} \mathrm{F} & \text { degrees Fahrenheit } \\ \mu \mathrm{Ci} / \mathrm{g} & \text { microcuries per gram } \\ \mu \mathrm{Ci} / \mathrm{mL} & \text { microcuries per milliliter } \\ \mu \mathrm{eq} / \mathrm{g} & \text { microequivalents per gram } \\ \mu \mathrm{g} / \mathrm{g} & \text { micrograms per gram } \\ \mu \mathrm{g} / \mathrm{mL} & \text { micrograms per milliliter } \\ \Delta \mathrm{H} & \text { change in enthalpy }\end{array}$




\subsection{INTRODUCTION}

This tank characterization report presents an overview of double-shell tank 241-AN-101 and its waste contents. It provides estimated concentrations and inventories for the waste components based on the latest sampling and analysis activities in combination with background tank information. The characterization of tank 241-AN-101 is based on two grab sampling events which occurred in August/September and December 1995.

Tank 241-AN-101 is still in service and may continue to transfer or receive waste. Consequently, the composition of the tank waste may change depending on the waste types received. The concentration and inventory values reported in this document reflect the best estimates based on available data. This report supports the requirements of the Hanford Federal Facility Agreement and Consent Order, Milestone M-44-09 (Ecology et al. 1994).

\subsection{PURPOSE}

The purpose of this report is to summarize the information about the use and contents of tank 241-AN-101. This information will be used to assess issues associated with safety, operations, environmental, and process development activities. This report also serves as a reference point for more detailed information about tank 241-AN-101.

\subsection{SCOPE}

The August/September 1995 grab sampling event was performed to satisfy the requirements of the Data Quality Objectives for the Waste Compatibility Program (Fowler 1995). Three grab samples were taken at different depths from one riser. As required by the DQO, the following analyses were performed: differential scanning calorimetry (DSC) for energetics, thermogravimetric analysis (TGA) for moisture content, furnace oxidation for TOC and TIC, gamma energy analysis (GEA) for ${ }^{137} \mathrm{Cs}$, beta proportional counting for ${ }^{90} \mathrm{Sr}$, inductively coupled plasma spectroscopy (ICP) for $\mathrm{Al}, \mathrm{Fe}$, and $\mathrm{Na}$, titration for $\mathrm{OH}^{\circ}$, ion chromatography (IC) for $\mathrm{Cl}^{-}, \mathrm{F}, \mathrm{NO}_{2}{ }^{-}, \mathrm{NO}_{3}{ }^{-}, \mathrm{PO}_{4}{ }^{3-}$, and $\mathrm{SO}_{4}{ }^{2-}, \mathrm{pH}$, alpha proportional counting for ${ }^{241} \mathrm{Am}$ and ${ }^{239 / 240} \mathrm{Pu}$, specific gravity, centrifugation for percent solids, and a visual check for an organic layer.

A decision was made later to conduct a safety screening evaluation on the tank according to the Tank Safety Screening Data Quality Objective (Dukelow et al. 1995). A set of three grab samples was taken from the tank in December 1995. The following five analyses were performed on the recovered waste: DSC, TGA, total alpha activity analysis, density, and a visual check for an organic layer. As also required by the safety screening DQO, tank vapors were field tested using a combustible gas meter. The number of analyses was small because of the narrow focus of the sampling event, that is, verification of the non-Watch List status of the tank and/or identification of any unknown safety issues. 
WHC-SD-WM-ER-578 Rev. 0

This page intentionally left blank. 


\subsection{HISTORICAL TANK INFORMATION}

This section describes tank 241-AN-101 based on historical information. The first part details the current condition of the tank. This is followed by discussions of the tank's background, transfer history, and the process sources that contributed to the tank waste, including an estimate of the current contents based on the process history. Events that may be related to tank safety issues, such as potentially hazardous tank contents or off-normal operating temperatures, are included. The final part summarizes available surveillance data for the tank. Solid and liquid level data are used to determine tank integrity (leaks) and to provide clues to internal activity in the solid layers of the tank. Temperature data are provided to evaluate the heat generating characteristics of the waste.

\subsection{TANK STATUS}

As of December 31, 1995, tank 241-AN-101 contained an estimated 4,090 kL (1,080 kgal) of dilute noncomplexed waste (Hanlon 1996). Liquid volume was determined using a combination of a Food Instrument Corporation (FIC) automatic surface level gauge and a manual tape surface level gauge. Solids volume was determined using a sludge level measurement device. Table 2-1 shows the volume of the waste phases found in the tank.

Table 2-1. Estimated Tank Contents (December 1996). ${ }^{1,2}$

\begin{tabular}{|c|c|c|}
\hline Waste ronul & & \\
\hline 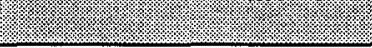 & (1. & Isgat \\
\hline Total waste & 4,090 & 1,080 \\
\hline Supernatant liquid & 4,090 & 1,080 \\
\hline Drainable interstitial liquid & 0 & 0 \\
\hline Drainable liquid remaining & 4,090 & 1,080 \\
\hline Pumpable liquid remaining & 4,090 & 1,080 \\
\hline Sludge & 0 & 0 \\
\hline Saltcake & 0 & 0 \\
\hline
\end{tabular}

Note:

${ }^{1}$ Hanlon (1996)

2Because tank 241-AN-101 is an active tank, the waste volumes in this table may not reflect current tank contents. 
Tank 241-AN-101 is an active dilute receiver and receives noncomplexed saltwell waste. It is actively ventilated and categorized as sound. Currently, the waste is classified as dilute noncomplexed. This tank is not on any Watch Lists. All monitoring systems were in compliance with documented standards as of December 31, 1995 (Hanlon 1996).

\subsection{TANK DESIGN AND BACKGROUND}

The AN Tank Farm is the newest generation double-shell design tank farm. It was built between 1980 and 1981 . The tank farm consists of seven type 100 series, $4,390 \mathrm{~kL}$ $(1,160 \mathrm{kgal})$ tanks. The tanks were designed to hold concentrated supernatant with a maximum fluid temperature of $177^{\circ} \mathrm{C}\left(350^{\circ} \mathrm{F}\right)$. The AN Tank Farm does not use a cascade system between tanks. Tank 241-AN-101 has 61 risers ranging in diameter from $10 \mathrm{~cm}$ (4 in.) to $107 \mathrm{~cm}$ ( $42 \mathrm{in}$.) that provide surface level access to the underground tank and annulus. This tank has five risers available for sampling: three $10 \mathrm{~cm}(4 \mathrm{in}$.) risers $(10 \mathrm{~A}$, $15 \mathrm{~B}$, and $21 \mathrm{~A}$ ) and two $30 \mathrm{~cm}$ (12 in.) risers (7B and 12A). If used as sampling ports, the risers would access a wide area of the north half of the tank and one point in the south half of the tank.

Tank 241-AN-101 entered service in September 1981. It is constructed of 0.46-m (1.5-ft) thick concrete walls and a $0.38-\mathrm{m}(1.25-\mathrm{ft})$ thick concrete dome. The mild carbon steel liner on the bottom is $1.3 \mathrm{~cm}(0.5 \mathrm{in}$.) thick, and the lower part of the sides are $1.9 \mathrm{~cm}(0.75 \mathrm{in})$. The upper part of the sides are $1.3 \mathrm{~cm}(0.5 \mathrm{in}$.) thick, and the dome liner is $0.95-\mathrm{cm}$ (0.375-in.) thick steel. The inner liner has been heat-treated and stress-relieved. The secondary liner is made of $0.95 \mathrm{~cm}$ (0.375 in.) mild carbon steel. The outer liner has not been heat-treated. The tank has a flat bottom and an $11.8 \mathrm{~m}(38.6 \mathrm{ft})$ liner height with a maximum operating depth of $10.7 \mathrm{~m}(35.2 \mathrm{ft})$. In addition, the tank has a grid of drain slots beneath the steel liner bottom. The grid collects any leaks that may occur and diverts them to a leak detection well. The grid also serves as an escape route for free water formed as it is released from the concrete grout during the initial heating of the tank. The bottom center elevation of tank $241-\mathrm{AN}-101$ is $186.76 \mathrm{~m}(612.74 \mathrm{ft})$. The tank is set on an insulated, reinforced concrete foundation. Coatings and sealants were used to ensure that no leaks and intrusions exist.

Table 2-2 lists tank 241-AN-101 risers and shows their size and typical use. Annulus risers are not included in this table. Figure 2-1 shows the riser configurations and locations. Figure 2-2 shows a tank cross section with the approximate waste level and a schematic of the tank equipment. 
WHC-SD-WM-ER-578 Rev. 0

Table 2-2. Tank 241-AN-101 Risers. ${ }^{1}$

\begin{tabular}{|c|c|c|c|}
\hline $\begin{array}{l}\text { Nev } \\
\text { Riser } \\
\text { Munber }\end{array}$ & Murver & Dinimeter & bescription and Gominents? \\
\hline 102 & $1 \mathrm{~A}$ & 4 & $\begin{array}{l}\text { Sludge measurement port; manual tape surface level } \\
\text { gauge }\end{array}$ \\
\hline 103 & $1 \mathrm{~B}$ & 4 & Sludge measurement port \\
\hline 101 & $1 \mathrm{C}$ & 4 & $\begin{array}{l}\text { Sludge measurement port with } 12 \text { in. cover and } \\
\text { protective concrete pad }\end{array}$ \\
\hline 104 & $2 \mathrm{~A}$ & 4 & FIC surface level gauge \\
\hline 105 & $3 \mathrm{~A}$ & 12 & Supernatant pump, central pump pit \\
\hline 106 & $4 \mathrm{~A}$ & 4 & Thermocouple tree \\
\hline 108 & $5 \mathrm{~A}$ & 42 & Manhole \\
\hline 107 & $5 \mathrm{~B}$ & 42 & Manhole \\
\hline 112 & $7 \mathrm{~A}$ & 12 & Tank ventilation \\
\hline 111 & $7 \mathrm{~B}$ & 12 & Spare \\
\hline 125 & $10 \mathrm{~A}$ & 4 & Flush pit drain, spare \\
\hline 126 & $11 \mathrm{~A}$ & 42 & Slurry distributor, central pump pit \\
\hline 127 & $12 \mathrm{~A}$ & $\overline{12}$ & Observation port, spare \\
\hline 128 & $13 \mathrm{~A}$ & 4 & Tank pressure \\
\hline 129 & $14 \mathrm{~A}$ & 4 & Supernatant return, central pump pit \\
\hline 131 & $15 \mathrm{~A}$ & 4 & High liquid level sensor \\
\hline 130 & $15 B$ & 4 & Spare \\
\hline 134 & $16 \mathrm{~A}$ & 4 & Sludge measurement port \\
\hline 132 & $16 \mathrm{~B}$ & 4 & Sludge measurement port \\
\hline 133 & $16 \mathrm{C}$ & 4 & Sludge measurement port \\
\hline 155 & $21 \mathrm{~A}$ & 4 & Spare \\
\hline 156 & $22 \mathrm{~A}$ & 4 & Sludge measurement port \\
\hline 160 & $24 \mathrm{~A}$ & 6 & Supernatant receiver (pit) \\
\hline 161 & $25 \mathrm{~A}$ & 8 & Condensate receiver (pit) \\
\hline
\end{tabular}

Notes:

'Alstad (1992), Vitro Engineering Corporation (1987), WHC (1992)

${ }^{2}$ Denotes Engineering Change Notice 613266, dated January 20, 1995 made against the referenced drawings.

${ }^{3}$ Annulus risers are not included in this table. 
Figure 2-1. Riser Configuration for Tank 241-AN-101.

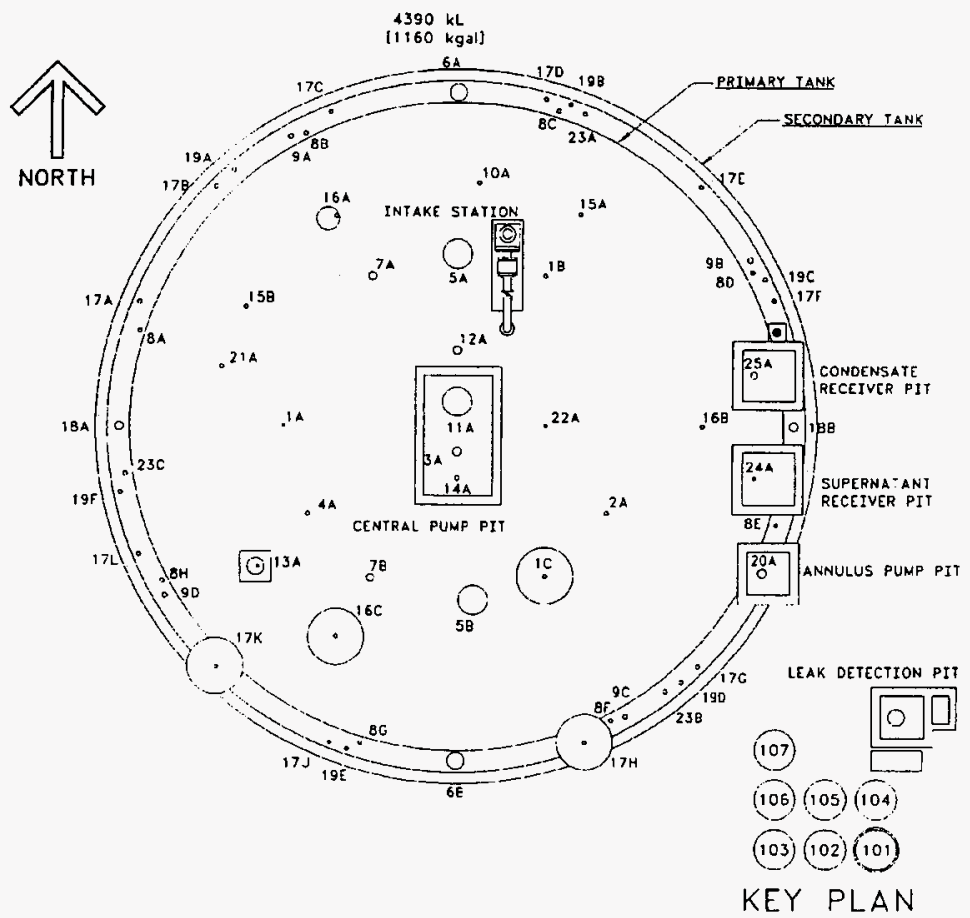


Figure 2-2. Tank 241-AN-101 Cross Section.

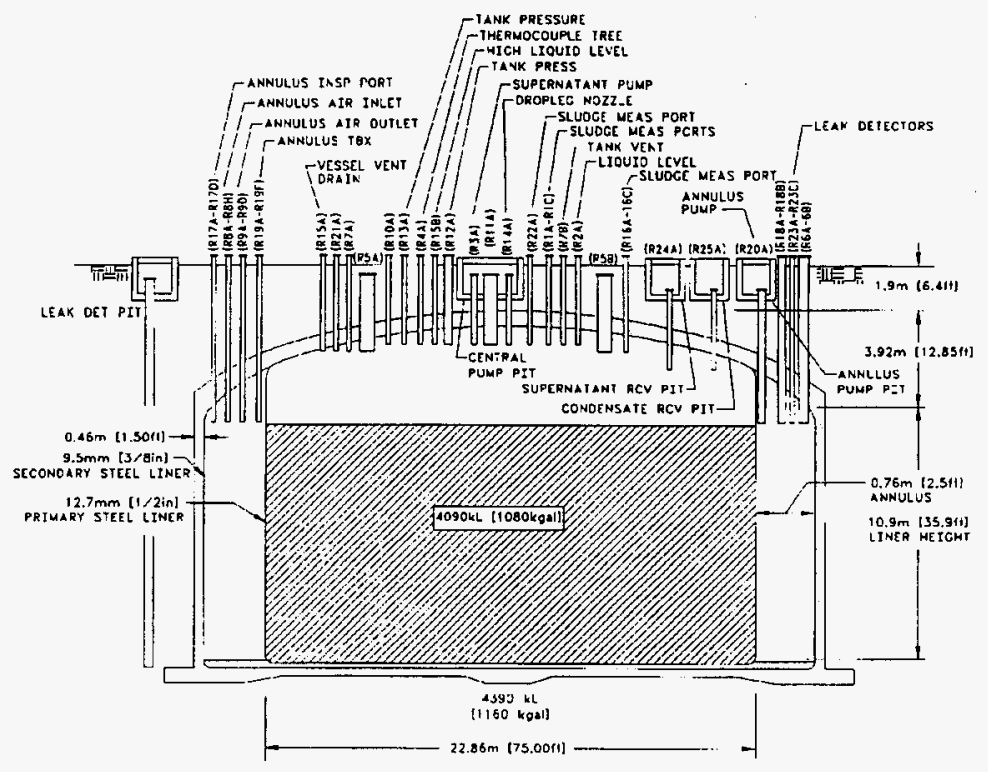




\subsection{PROCESS KNOWLEDGE}

This section presents the transfer history of tank 241-AN-101. The major waste receipts prior to 1994 are taken from the Waste Status and Transaction Record Summary for the Southeast Quadrant of the Hanford 200 Area (Agnew et al. 1996) (see Section 2.3.1 and Table 2-3). The post-1993 data are from a database developed for waste volume projections and have not been validated (see Section 2.3.2 and Table 2-4). Section 2.3.3 describes the historical estimate of the tank's waste contents.

\subsubsection{Waste Transfer History Prior to 1994}

PUREX low-level waste was transferred to tank 241-AN-101 in September 1981. Water was added to tank 241-AN-101 from the fourth quarter of 1981 until the second quarter of 1982. During the fourth quarter of 1981 , an unknown waste type was transferred from tank 241-AN-101 to tank 241-AN-106.

From the third quarter of 1982 until the second quarter of 1985 , tank $241-A N-101$ received additional low-level waste from PUREX. From the second quarter of 1983 until the first quarter of 1992, tank 241-AN-101 received dilute, noncomplexed liquid waste pumped from saltwells in single-shell tanks in the 200 East and West Areas. Table 2-3 lists the tanks involved in the pumping and waste transfer. From the fourth quarter of 1983 until the fourth quarter of 1988, tank 241-AN-101 transferred liquid waste to tank 241-AW-102. This transfer was used for the 242-A Evaporator as a liquid feed source.

Agnew et al (1996) indicates that tank 241-AN-101 received an unknown waste type from tanks 241-AY-102, 241-AW-105, and 241-AN-103 during 1984. Tank 241-AN-101 also transferred an unknown waste type to tanks 241-AN-102, 241-AZ-102, 241-AW-101 and 241-AN-103. According to historical records, these were transfers of noncomplexed waste. Additional waste was added to tank 241-AN-101 from B Plant low-level waste operations.

Additional low-level waste from PUREX was added in the second quarter of 1985 . In the third quarter of 1985, the tank received concentrated phosphate waste from $\mathrm{N}$ Reactor. During the second quarter of 1987, tank 241-AN-101 received waste from tank 241-AW-102. 
Table 2-3. Summary of Incoming Waste Transfer History Prior to $1994 .^{1.2}$

\begin{tabular}{|c|c|c|c|c|}
\hline \multirow{2}{*}{ T: Transfer Source } & \multirow[b]{2}{*}{ Waste Type Received } & \multirow{2}{*}{$\begin{array}{l}\text { Tine } \\
\text { Period }\end{array}$} & \multicolumn{2}{|c|}{$\begin{array}{l}\text { Tstimated Waste } \\
\text { yolune }\end{array}$} \\
\hline & & & kI & igal \\
\hline A Plant (PUREX) & PUREX low-level waste & $\begin{array}{l}1981 \text { to } \\
1983\end{array}$ & 1,064 & 281 \\
\hline $\begin{array}{l}241 \text { tanks: A-102, } \\
\text { AX-101, AX-102, AX-103, } \\
\text { B-104, B-106, B-107, } \\
\text { B-108, B-110, BX-104, } \\
\text { BX-105, BX-107, BX-109, } \\
\text { BX-110, BX-111, BX-112, } \\
\text { BY-102, BY-103, BY-104, } \\
\text { C-105, C-107, S-105, } \\
\text { S-108, S-111, S-112, } \\
\text { T-109, T-111, TX-113, } \\
\text { TX-116, U-101 }\end{array}$ & $\begin{array}{l}\text { Saltwell liquid from listed } \\
\text { single-shell tanks }\end{array}$ & $\begin{array}{c}1983 \text { to } \\
1992\end{array}$ & 4,652 & 1,229 \\
\hline 241-AY-102 & $\begin{array}{l}\text { Supernatant from } \\
\text { tank 241-AY-102 }\end{array}$ & 1984 & 659 & 174 \\
\hline 241-AW-105 & $\begin{array}{l}\text { Supernatant from } \\
\text { tank 241-AW-105 }\end{array}$ & 1984 & 935 & 247 \\
\hline B Plant & B Plant low level waste & 1984 & 216 & 57 \\
\hline 241-AN-103 & $\begin{array}{l}\text { Supernatant from } \\
\text { tank 241-AN-103 }\end{array}$ & 1984 & 454 & 120 \\
\hline A Plant (PUREX) & PUREX low level waste & 1985 & 541 & 143 \\
\hline N Reactor & $\begin{array}{l}\text { Concentrated phosphate } \\
\text { waste from N Reactor }\end{array}$ & 1985 & 189 & 50 \\
\hline 241-AW-102 & $\begin{array}{l}\text { Dilute noncomplexed waste } \\
\text { from tank } 241-\mathrm{AW}-102\end{array}$ & 1987 & 1,333 & 352 \\
\hline
\end{tabular}

Notes:

\footnotetext{
'Agnew et al. 1996

${ }^{2}$ Waste volumes and types are best estimates based on historical data.
} 


\subsubsection{Waste Transfer History After January 1, 1994}

All transfer history information after January 1, 1994 was taken from a waste volume projection database. No discussion was provided with the transfer history data. The information should be used with caution because the data have not been validated. Table 2-4 shows the post-1993 transfer history data.

Unknown waste gains or losses in Table 2-4 may be the result of rounding calculations, clean water slowly leaking through a valve, changes in levels (expansion/contraction) because of ambient temperature changes, different measuring devices being used by tank farm operators, transfers taking place during the end of the month, tank farm activities such as miscellaneous water additions not associated with facility waste generation, or the additional water that is added to aging waste tanks and then evaporated off.

\subsubsection{Historical Estimation of Tank Contents}

The following is an estimate of the contents for tank 241-AN-101 based on historical transfer data. The historical data used for the estimate is the Waste Status and Transaction Record Summary for the Southeast Quadrant of the Hanford 200 Area (WSTRS) (Agnew et al. 1996), the Hanford Defined Waste: Chemical and Radionuclide Compositions (HDW) list (Agnew 1995), and the Tank Layer Model (TLM) (Agnew et al. 1995) from the Historical Tank Content Estimate for the Southeast Quadrant of the Hanford 200 Areas (HTCE) (Brevick et al. 1995a). The WSTRS is a compilation of waste transfer and volume status data. The HDW provides the assumed typical compositions for fifty separate waste types. In most cases, the data are incomplete, reducing the reliability of the transfer data and the modeling results derived from it. The TLM takes the WSTRS data, models the waste deposition processes, and using additional data from the HDW, generates an estimate of the tank contents. Several errors are introduced as the models are added to create the estimate. Thus, these model predictions can only be considered estimates which require further evaluation using analytical data.

As of December 31, 1995, tank 241-AN-101 contained an estimated 4,090 kL (1,080 kgal) of supernatant (Hanlon 1996). Because this tank is an active receiver of dilute noncomplexed waste, the waste volume and content will continue to vary. Therefore, the TLM and inventory estimates should be used with caution. Based on the HTCE and the TLM, tank 241-AN-101 contained 2,650 kL (700 kgal) of supernatant waste as of January 1, 1994. Table 2-5 presents an estimate of the expected waste constituents and concentrations. 
WHC-SD-WM-ER-578 Rev. 0

Table 2-4. Summary of tank 241-AN-101 Waste Transfer History after January 1, 1994. ${ }^{1}$

\begin{tabular}{|c|c|c|c|c|c|c|}
\hline \multirow{2}{*}{ Woost } & \multirow{2}{*}{ grom } & \multirow{2}{*}{ (6) } & \multirow{2}{*}{ Staturyate } & \multirow{2}{*}{ Enid Pate } & \multicolumn{2}{|c|}{ 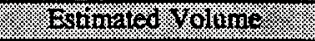 } \\
\hline & & & & & . & . \\
\hline GA & SWLIQ & & $1 / 6 / 94$ & $1 / 8 / 94$ & 61 & 16 \\
\hline LO & & UNKN* $^{*}$ & $2 / 1 / 94$ & $2 / 28 / 94$ & -4 & -1 \\
\hline GA & SWLIQ & & $3 / 22 / 94$ & $3 / 22 / 94$ & 68 & 18 \\
\hline GA & SWLIQ & & $4 / 10 / 94$ & $4 / 25 / 94$ & 129 & 34 \\
\hline$\overline{G A}$ & UNKN & & $5 / 1 / 94$ & $5 / 31 / 94$ & 4 & 1 \\
\hline GA & SWLIQ & & $6 / 11 / 94$ & $6 / 11 / 94$ & 64 & 17 \\
\hline $\mathrm{GA}$ & SWLIQ & & $6 / 29 / 94$ & $6 / 29 / 94$ & 49 & 13 \\
\hline GA & SWLIQ & & $7 / 17 / 94$ & $7 / 17 / 94$ & 49 & 13 \\
\hline$\overline{G A}$ & UNKN & & $9 / 1 / 94$ & $9 / 30 / 94$ & 4 & 1 \\
\hline GA & SWLIQ & & $10 / 15 / 94$ & $10 / 15 / 94$ & 38 & 10 \\
\hline GA & SWLIQ & & $11 / 19 / 94$ & $11 / 19 / 94$ & 45 & 12 \\
\hline GA & SWLIQ & & $1 / 23 / 95$ & $1 / 23 / 95$ & 45 & 12 \\
\hline GA & SWLIQ & & $2 / 28 / 95$ & $2 / 28 / 95$ & 61 & 16 \\
\hline LO & & UNKN & $3 / 1 / 95$ & $3 / 31 / 95$ & -4 & -1 \\
\hline LO & & UNKN & $4 / 1 / 95$ & $4 / 30 / 95$ & -4 & -1 \\
\hline $\mathrm{LO}$ & & UNKN & $5 / 1 / 95$ & $5 / 31 / 95$ & -4 & -1 \\
\hline GA & SWLIQ & & $6 / 30 / 95$ & $6 / 30 / 95$ & 30 & 8 \\
\hline GA & SWLIQ & & $7 / 12 / 95$ & $7 / 12 / 95$ & 34 & 9 \\
\hline $\mathrm{GA}$ & SWLIQ & & $8 / 12 / 95$ & $8 / 29 / 95$ & 204 & 54 \\
\hline $\mathrm{GA}$ & SWLIQ & & $9 / 8 / 95$ & $9 / 8 / 95$ & 68 & 18 \\
\hline $\mathrm{GA}$ & SWLIQ & & $9 / 15 / 95$ & $9 / 15 / 95$ & 68 & 18 \\
\hline GA & UNKN & & $10 / 1 / 95$ & $10 / 31 / 95$ & 8 & 2 \\
\hline GA & SWLIQ & & $10 / 14 / 95$ & $10 / 14 / 95$ & 64 & 17 \\
\hline GA & INST $^{2}$ & & $10 / 14 / 95$ & $10 / 14 / 95$ & 11 & 3 \\
\hline $\mathrm{GA}$ & UNKN & & $7 / 1 / 96$ & $7 / 31 / 96$ & 4 & 1 \\
\hline
\end{tabular}

Notes:

$\mathrm{GA}=$ volume gain

$L O=$ volume loss

UNKN = unknown waste type

SWLIQ $=$ waste from single-shell tank saltwell pumping

'The table data have not been validated and are the best estimates based on the available information.

${ }^{2}$ Change in instrumentation baseline (FIC failed, currently using manual tape). 
Table 2-5. Double-Shell Tank 241-AN-101 Historical Inventory Estimate. ${ }^{1,2}$ (2 sheets)

\begin{tabular}{|c|c|c|c|}
\hline 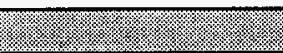 & Hal inyenuor EStur & ate & \\
\hline 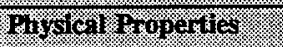 & 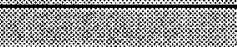 & & (1.3. \\
\hline Total waste & $2.69 \mathrm{E}+06 \mathrm{~kg}(700$ & kgal) & \\
\hline Heat load & $102 \mathrm{~W} \mathrm{(349 \textrm {Btu } / \mathrm { hr }}$ & & \\
\hline Bulk density ${ }^{3}$ & $1.01 \mathrm{~g} / \mathrm{mL}$ & & \\
\hline Water wt $\%^{3}$ & 97.6 & & \\
\hline $\begin{array}{l}\text { Total Organic Carbon } \\
\text { wt\% Carbon (wet) }\end{array}$ & 0.032 & & \\
\hline Chernici Constifuents & (3.) & ppm & $16 \%$ \\
\hline $\mathrm{Na}^{+}$ & 0.302 & 6,860 & 18,400 \\
\hline$\overline{\mathrm{Al}^{3+}}$ & 0.0329 & 877 & 2,350 \\
\hline $\mathrm{Fe}^{3+}$ (total $\left.\mathrm{Fe}\right)$ & $2.97 \mathrm{E}-04$ & 16.4 & 44.0 \\
\hline $\mathrm{Cr}^{3+}$ & 0.00106 & 54.2 & 145 \\
\hline$\overline{\mathrm{Bi}^{3+}}$ & $2.32 \mathrm{E}-05$ & 4.79 & 12.9 \\
\hline $\mathrm{La}^{3+}$ & $1.02 \mathrm{E}-07$ & 0.0139 & 0.0374 \\
\hline $\mathrm{Hg}^{2+}$ & $4.41 \mathrm{E}-07$ & 0.0872 & 0.234 \\
\hline $\mathrm{Zr}$ (as $\left.\mathrm{ZrO}(\mathrm{OH})_{2}\right)$ & $1.02 \mathrm{E}-04$ & 9.19 & 24.7 \\
\hline $\mathrm{Pb}^{2+}$ & $3.39 \mathrm{E}-06$ & 0.692 & 1.86 \\
\hline $\mathrm{Ni}^{2+}$ & $2.12 \mathrm{E}-04$ & 12.3 & 33.1 \\
\hline $\mathrm{Sr}^{2+}$ & $1.07 \mathrm{E}-07$ & 0.00928 & 0.0249 \\
\hline $\mathrm{Mn}^{4+}$ & $4.14 \mathrm{E}-04$ & 22.4 & 60.3 \\
\hline $\mathrm{Ca}^{2+}$ & 0.00208 & 82.3 & 221 \\
\hline $\mathrm{K}^{+}$ & 0.00731 & 282 & 757 \\
\hline $\mathrm{OH}^{-}$ & 0.150 & 2,520 & 6,770 \\
\hline $\mathrm{NO}_{3}^{-}$ & 0.131 & 8,040 & 21,600 \\
\hline $\mathrm{NO}_{2}^{-}$ & 0.0396 & 1,800 & 4,830 \\
\hline
\end{tabular}


Table 2-5. Double-Shell Tank 241-AN-101 Historical Inventory Estimate. ${ }^{1,2}$ (2 sheets)

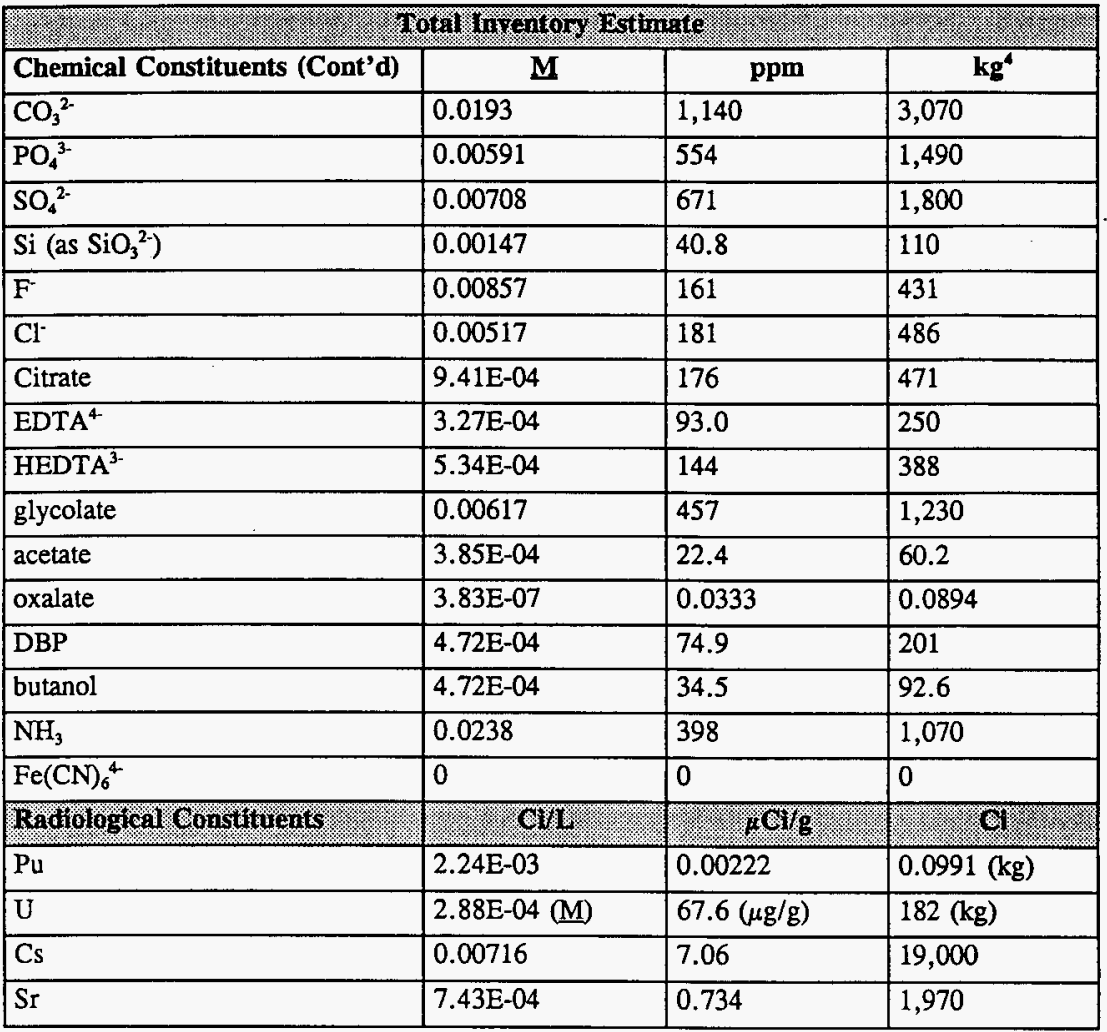

Notes:

'Brevick et al. (1995a)

'The HTCE predictions have not been validated and should be used with caution.

${ }^{3}$ Volume average for density; mass average water wt $\%$ and TOC wt $\%$ C.

"Small differences appear to exist among the inventories in this column and the inventories calculated from the two sets of concentrations. These differences are being evaluated. 


\subsection{SURVEILLANCE DATA}

Tank 241-AN-101 surveillance consists of surface level measurements (liquid and solid), temperature monitoring inside the tank (waste and vapor space), and leak detection well monitoring for radioactive liquids outside the primary tank. The surveillance data provide the basis for determining tank integrity.

Liquid level measurements show major leaks in or out of the tank. Solid surface level measurements indicate the physical changes and consistency of the tank's solid layers. However, because of the nature of the waste received in tank 241-AN-101, solids are either suspended or dissolved and are not a significant contributor to the waste volume. Leak detection systems within the tank annulus will detect leaks from the primary tank and prevent leaks to the soil.

\subsubsection{Surface Level Readings}

The tank 241-AN-101 surface level is monitored with a Food Instrument Corporation gauge and a manual tape. Because this is an active tank, the surface level is continually subject to change. The surface level on March 21, 1996 was $9.977 \mathrm{~m}$ (392.8 in.), which equals approximately $4,090 \mathrm{~kL}(1,080 \mathrm{kgal})$. Figure $2-3$ shows a level history graph of the volume measurements.

\subsubsection{Internal Tank Temperatures}

Temperature data for tank 241-AN-101 are recorded by 18 thermocouples on one thermocouple tree located in riser 4A. Non-suspect temperature data from the Computer Automated Surveillance System, recorded from July 1983 to May 1986, are available for all 18 thermocouples. Non-suspect temperature data from the Surveillance Analysis Computer System recorded from January 1990 to March 1996 are available for six thermocouples. Therefore, a gap in the temperature data exists between May 1986 and January 1990 . The average temperature of all temperature data from July 1983 to March 1996 was $22.1{ }^{\circ} \mathrm{C}$ $\left(71.8^{\circ} \mathrm{F}\right)$, the minimum temperature was $11^{\circ} \mathrm{C}\left(52^{\circ} \mathrm{F}\right)$, and the maximum temperature was $32.4^{\circ} \mathrm{C}\left(90.3^{\circ} \mathrm{F}\right)$. Figure $2-4$ shows a graph of the weekly high temperature. The high tank temperatures in the second quarter of 1995 are probably caused by the waste transfers from 244-A to tank 241-AN-101 that occurred in April; May, and June. Plots of the individual thermocouple readings for tank 241-AN-101 can be found in the supporting documents for the HTCE (Brevick et al. 1995b).

\subsubsection{Tank 241-AN-101 Photograph}

No interior photograph is available. 
Figure 2-3. Tank 241-AN-101 Level History.

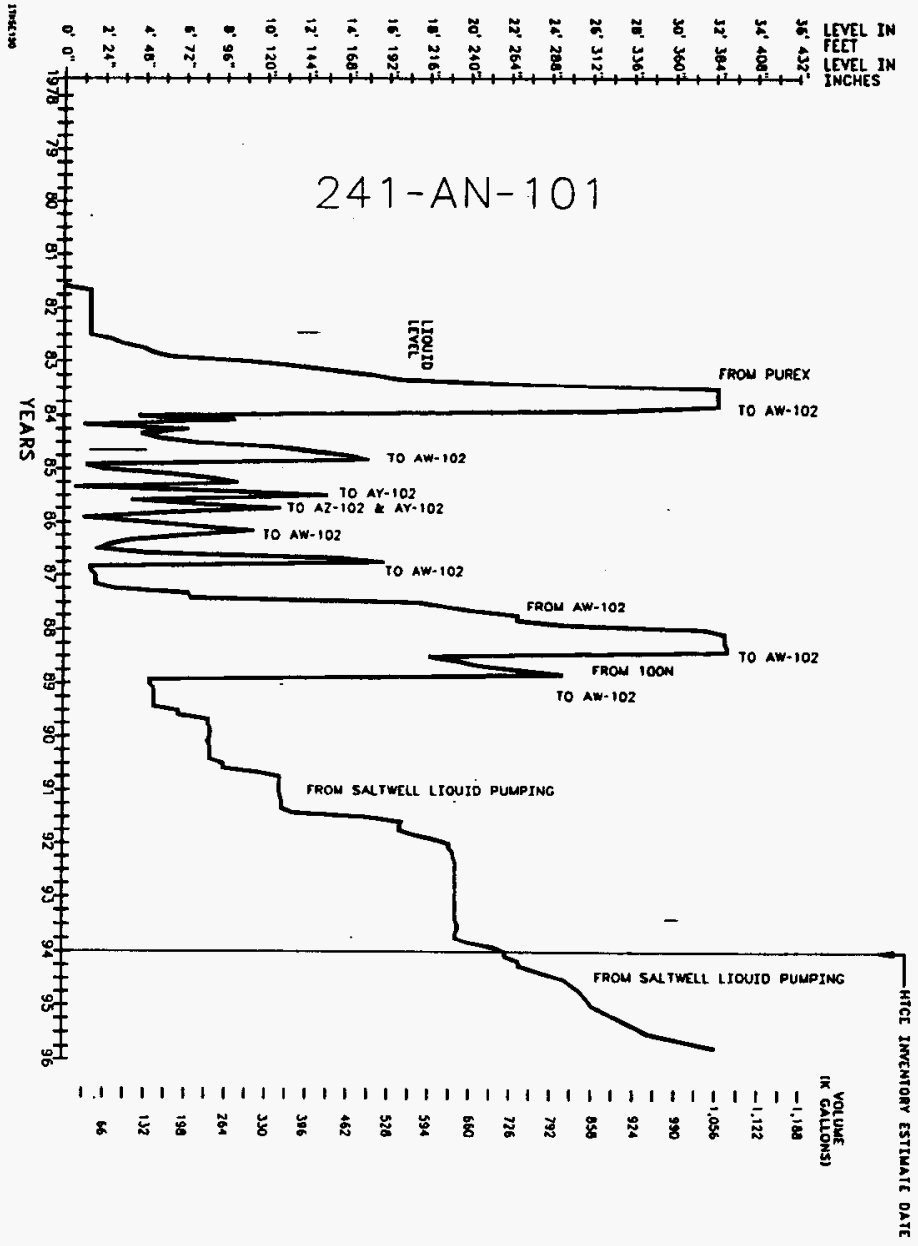


Figure 2-4. Tank 241-AN-101 Weekly High Temperature Plot.

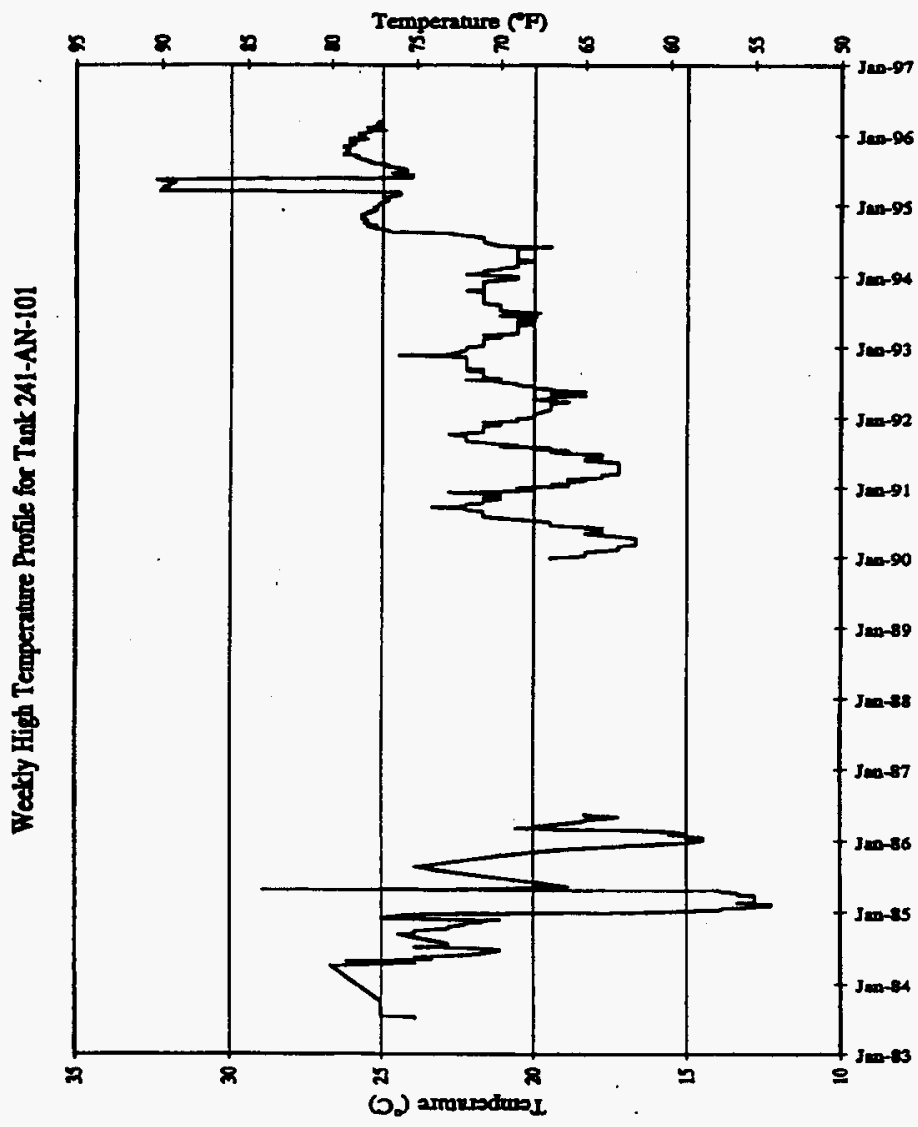




\subsection{TANK SAMPLING OVERVIEW}

This section describes the August/September 1995 and the December 1995 grab sampling and analysis events for tank 241-AN-101. Grab samples 1AN-95-1, 1AN-95-2, and 1AN-95-3 were obtained in August and September 1995 to satisfy the requirements of the Data Quality Objectives for the Waste Compatibility Program (Fowler 1995). The sampling and analyses were performed in accordance with the Compatibility Grab Sampling Analysis Plan (Jones 1995). Grab samples 1AN-95-4, 1AN-95-5, and 1AN-95-6 were obtained in December 1995 to support safety screening analyses. The safety screening analyses were performed to satisfy the requirements of the Tank Safety Screening Data Quality Objective (Dukelow et al. 1995) and were carried out in accordance with the Tank 241-AN-101 Grab Sampling and Analysis Plan (Benar 1995). For further discussions of the sampling and analysis procedures, refer to the Tank Characterization Reference Guide

(DeLorenzo et al. 1994).

\subsection{DESCRIPTION OF SAMPLING EVENTS}

Tank 241-AN-101 was grab sampled from riser 22A on August 31 and September 6, 1995, to obtain samples for the waste compatibility analyses. Sample 1AN-95-1 was taken on August 31, 1995 and was received by the Westinghouse Hanford Company 222-S Laboratory on September 1, 1995. Samples 1AN-95-2 and 1AN-95-3 were taken on September 6, 1995, and were received by the 222-S Laboratory the following day. The safety screening samples, designated as $1 \mathrm{AN}-95-4,1 \mathrm{AN}-95-5$, and $1 \mathrm{AN}-95-6$, were taken from riser $15 \mathrm{~B}$ on December 12, 1995, and were received by the 222-S Laboratory on December 13, 1995. A field blank, sample number $1 \mathrm{AN}-95-7$, was taken with the safety screening samples.

The bottle-on-a-string sampling method was chosen for obtaining both sample sets. Prior to the December 1995 sampling, the tank headspace was sampled through riser 15B and analyzed for flammable gas as prescribed by the safety screening DQO. Table 3-1 summarizes the sampling mode, applicable DQOs, and sampling and analytical requirements for the sampling events. 
Table 3-1. Integrated Data Quality Objective Requirements for Tank 241-AN-101. ${ }^{1,2}$

\begin{tabular}{|c|c|c|c|}
\hline Sampling Event & Woplicable & Sampling & Analyicul Requirenents \\
\hline $\begin{array}{l}\text { December } 1995 \\
\text { grab sampling }\end{array}$ & $\begin{array}{l}\text { Safety screening } \\
\text { (Dukelow et al. } \\
\text { 1995) }\end{array}$ & $\begin{array}{l}\text { Vertical profiles } \\
\text { from two widely } \\
\text { spaced risers }\end{array}$ & $\begin{array}{l}\text { - Energetics } \\
\text { - Moisture content } \\
\text { - Total alpha activity } \\
\text { - Density } \\
\text { - Visual check for presence of } \\
\text { organic layer } \\
\text { - Headspace gas flammability }\end{array}$ \\
\hline $\begin{array}{l}\text { August/September } \\
1995 \text { grab } \\
\text { sampling }\end{array}$ & $\begin{array}{l}\text { Waste } \\
\text { compatibility } \\
\text { (Fowler 1995) }\end{array}$ & $\begin{array}{l}\text { Grab samples } \\
\text { from different } \\
\text { depths }\end{array}$ & $\begin{array}{l}\text { - Energetics } \\
\text { - Moisture content } \\
\text { - Metals by ICP } \\
\text { - Anions by IC } \\
\text { - Radionuclides } \\
\text { - Total carbon } \\
\text { - Hydroxide } \\
\text { - Density } \\
\text { - pH } \\
\text { - Percent solids } \\
\text { - Visual check for presence of } \\
\text { organic layer }\end{array}$ \\
\hline
\end{tabular}

Notes:

'Jones (1995)

${ }^{2} \operatorname{Benar}(1995)$

\subsection{SAMPLE HANDLING}

The grab samples were shipped to the 222-S Laboratory for subsampling and analysis.

Samples 1AN-95-1, 1AN-95-2, and 1AN-95-3 were assigned labcore numbers S95T002405, S95T002406, and S95T002407, respectively; they were subsampled on September 20, 1995. Samples 1AN-95-4, 1AN-95-5, and 1AN-95-6 were subsampled on December 15, 1995, and were assigned labcore numbers S95T003909, S95T003910, S95T003911, and S95T003912 (field blank), respectively. All samples were subjected to visual inspection for color, clarity, and solids content; over-the-top radiation measurements were taken. All samples were a clear, yellow liquid (except for the field blank which was colorless) with no visible solids and no organic layer. The samples were then subsampled into portions for the different analyses and for archiving. Table 3-2 provides a description of the samples. 
Table 3-2. Grab Sample Descriptions. ${ }^{1}$

\begin{tabular}{|c|c|c|c|c|c|}
\hline \multirow[b]{2}{*}{ Riser } & \multirow[b]{2}{*}{ Customer 10} & \multirow{2}{*}{$\begin{array}{l}\text { (Ziboratory } \mathrm{m} \\
\text { (Labcore Number) }\end{array}$} & $\begin{array}{l}\text { Sample } \\
\text { Elevation }\end{array}$ & $\begin{array}{l}\text { Somple } \\
\text { Yoline }\end{array}$ & $\begin{array}{l}\text { Over-the Top } \\
\text { Radiation }\end{array}$ \\
\hline & & & n $(\mathrm{fin})$ & mi: & . 1 riadhr \\
\hline \multirow[t]{3}{*}{$22 \mathrm{~A}$} & $1 \mathrm{AN}-95-1$ & S95T002405 & $\begin{array}{l}8.76 \\
(345)\end{array}$ & 125 & 3,500 \\
\hline & $1 \mathrm{AN}-95-2$ & S95T002406 & $\begin{array}{r}4.32 \\
(170)\end{array}$ & 125 & 4,500 \\
\hline & $1 \mathrm{AN}-95-3$ & S95T002407 & $\begin{array}{l}0.254 \\
(10)\end{array}$ & 125 & 4,500 \\
\hline \multirow[t]{4}{*}{$15 \mathrm{~B}$} & $1 \mathrm{AN}-95-4$ & S95T003909 & $\begin{array}{l}8.76 \\
(345)\end{array}$ & 125 & 7,000 \\
\hline & $1 \mathrm{AN}-95-5$ & S95T003910 & $\begin{array}{l}4.32 \\
(170)\end{array}$ & 125 & 7,500 \\
\hline & $1 \mathrm{AN}-95-6$ & S95T003911 & $\begin{array}{l}0.254 \\
(10)\end{array}$ & 125 & 5,000 \\
\hline & $\begin{array}{l}\text { AN-95-7 } \\
\text { (Field blank) }\end{array}$ & S95T003912 & $\begin{array}{l}11.0 \\
(432)\end{array}$ & 125 & $<0.5$ \\
\hline
\end{tabular}

Notes:

ID $=$ identification
$\mathrm{mrad} / \mathrm{hr}=$ millirads per hour

${ }^{1}$ Esch (1996)

${ }^{2}$ Sample elevation is the distance from the mouth of the sample bottle to the tank bottom. Note that the sample elevation of the field blank is above the waste surface.

\subsection{SAMPLE ANALYSIS}

Samples 1AN-95-1, 1AN-95-2, and 1AN-95-3 were assessed for waste compatibility. Analytes required for the waste compatibility evaluation include the following: energetics by DSC, weight percent water by TGA, TOC, GEA, ${ }^{90} \mathrm{Sr}, \mathrm{ICP}, \mathrm{OH}$, IC, pH, TIC, ${ }^{239 / 240} \mathrm{Pu}$, ${ }^{241} \mathrm{Am}$, density, percent solids, and a visual check for the presence of an organic layer. Waste compatibility analyses are used in controlling corrosion, evaluating waste rheology, avoiding mixing TRU and non-TRU waste, and preventing criticality.

Samples 1-AN-95-4, 1-AN-95-5, and 1 AN-95-6 were subjected to a safety screening evaluation. Safety screening analyses include: total alpha activity to determine the criticality potential; DSC to evaluate the fuel content; TGA to obtain the total moisture content; and density. The analysis of tank headspace gases for flammability is also required by the safety 
screening DQO. A combustible gas meter was used for the analyses. Table 3-1 summarizes the sampling and analytical requirements from the applicable DQOs.

The total alpha analyses were performed on archived samples from the August/September 1995 sampling event; however, the results were not used during the safety screening evaluation.

A brief discussion of the sample analyses, including a listing of the quality control measures used in the analyses follows. Table 3-3 summarizes the analyses performed on specific samples. The quality control tests for the safety screening analyses were performed and evaluated in accordance with Benar (1995); and tests for the waste compatibility analyses were performed in accordance with Jones (1995). Results of the quality control tests and the implications for data quality are discussed in Section 5.1.2.

\subsubsection{Thermal Analysis - Thermogravimetric Analysis and Differential Scanning Calorimetry}

Thermogravimetric analysis measures the rate of mass loss from the sample at a constant rate of temperature increase. The TGA scans are used to interpret thermal decomposition temperatures, water content, and reaction temperatures. Differential scanning calorimetry measures the heat released or absorbed by a sample while the temperature of the sample is increased at a constant rate. The DSC analyses are used to measure thermal decomposition temperatures, heats of reaction, reaction temperatures, melting points, and solid-solid transition temperatures.

Both TGA and DSC analyses were performed on samples whose mass ranged from $9.718 \mathrm{mg}$ to $28.00 \mathrm{mg}$. Quality control tests included duplicates and standards.

\subsubsection{Total Alpha Activity Analysis}

Analyses for total alpha activity, which indicate the potential of a substance to achieve criticality, were performed on all grab samples directly using an alpha proportional counter. Quality control tests included duplicates, blanks, standards, and spikes. 
WHC-SD-WM-ER-578 Rev. 0

Table 3-3. Tank 241-AN-101 Sample Analysis Summary.

\begin{tabular}{|c|c|c|c|}
\hline customer. ID & Wabcore Nerinber) & Gabcore rimber & Hnaissis: \\
\hline \multirow[t]{4}{*}{$1 \mathrm{AN}-95-1$} & \multirow[t]{4}{*}{ S95T002405 } & S95T002408 & $\begin{array}{l}\text { DSC, TGA, TOC, TIC, ICP } \\
\text { (Al, Fe, Na), IC (anions), pH, } \\
\mathrm{OH}^{-}, \mathrm{SpG}\end{array}$ \\
\hline & & S95T002411 & $\begin{array}{l}\mathrm{GEA}\left({ }^{137} \mathrm{Cs}\right),{ }^{239 / 240} \mathrm{Pu},{ }^{90} \mathrm{Sr} \\
{ }^{241} \mathrm{Am}\end{array}$ \\
\hline & & S95T003903 & Total alpha \\
\hline & & S95T003904 & Archive \\
\hline \multirow[t]{4}{*}{$1 \mathrm{AN}-95-2$} & \multirow[t]{4}{*}{ S95T002406 } & \$95T002409 & $\begin{array}{l}\text { DSC, TGA, TOC, TIC, ICP } \\
\text { (Al, Fe, Na), IC (anions), pH, } \\
\mathrm{OH}^{-}, \mathrm{SpG}\end{array}$ \\
\hline & & S95T002412 & $\begin{array}{l}\text { GEA }\left({ }^{137} \mathrm{Cs}\right),{ }^{239 / 240} \mathrm{Pu},{ }^{90} \mathrm{Sr} \\
{ }^{241} \mathrm{Am}\end{array}$ \\
\hline & & S95T003905 & Total alpha \\
\hline & & S95T003907 & Archive \\
\hline \multirow[t]{4}{*}{$1 \mathrm{AN}-95-3$} & \multirow[t]{4}{*}{ S95T002407 } & $\$ 95 T 002410$ & $\begin{array}{l}\text { DSC, TGA, TOC, TIC, ICP } \\
\text { (Al, Fe, Na), IC (anions), pH, } \\
\mathrm{OH}^{-}, \mathrm{SpG}\end{array}$ \\
\hline & & S95T002413 & $\begin{array}{l}\left.\text { GEA ( }{ }^{137} \mathrm{Cs}\right),{ }^{239 / 240} \mathrm{Pu},{ }^{90} \mathrm{Sr} \\
{ }^{241} \mathrm{Am}\end{array}$ \\
\hline & & S95T003906 & Total alpha \\
\hline & & S95T003908 & Archive \\
\hline $1 \mathrm{AN}-95-4$ & S95T003909 & S95T003913 & $\begin{array}{l}\text { DSC, TGA, SpG, total alpha, } \\
\text { archive }\end{array}$ \\
\hline $1 \mathrm{AN}-95-5$ & S95T003910 & S95T003914 & $\begin{array}{l}\text { DSC, TGA, SpG, total alpha, } \\
\text { archive }\end{array}$ \\
\hline $1 \mathrm{AN}-95-6$ & S95T003911 & S95T003915 & $\begin{array}{l}\text { DSC, TGA, SpG, total alpha, } \\
\text { archive }\end{array}$ \\
\hline $\begin{array}{l}1 \text { AN-95-7 } \\
\text { (Field blank) }\end{array}$ & S95T003912 & S95T003916 & $\begin{array}{l}\text { DSC, TGA, SpG, total alpha, } \\
\text { archive }\end{array}$ \\
\hline
\end{tabular}

Note:

$S_{\mathrm{p}} G=$ specific gravity 


\subsubsection{Specific Gravity}

Specific gravity measurements, used to convert the safety screening DQO total alpha activity notification limit from $\mathrm{g} / \mathrm{L}$ to $\mu \mathrm{Ci} / \mathrm{mL}$ and to evaluate the physical condition of the waste, were performed on all grab samples. Quality control tests included duplicate analyses and standards.

\subsubsection{Gamma Energy Analysis}

Gamma energy analyses, specifically required by the waste compatibility DQO for ${ }^{137} \mathrm{Cs}$, were performed directly on the waste compatibility samples (see Section 3.3). Results for ${ }^{60} \mathrm{Co}$ and ${ }^{134} \mathrm{Cs}$ were also recorded. Quality control tests included standards, blanks, and duplicate samples.

\subsubsection{Inductively Coupled Plasma/Atomic Emission Spectroscopy}

Inductively coupled plasma/atomic emission spectroscopy analyses were performed following acid dilution on the waste compatibility samples. These analyses were performed for $\mathrm{Al}, \mathrm{Na}$, and $\mathrm{Fe}$ to assess waste type and for criticality analyses as described by the waste compatibility DQO. Quality control tests included standards, blanks, duplicate samples, and spike recoveries.

\subsubsection{Ion Chromatography}

Ion chromatography analyses were performed following acid dilution on the waste compatibility samples. These analyses were performed for $\mathrm{Cl}^{-}, \mathrm{F}, \mathrm{NO}_{2}^{-}, \mathrm{NO}_{3}^{-}, \mathrm{PO}_{4}^{-}$, and $\mathrm{SO}_{4}{ }^{-}$to determine corrosion and leakage potential, as described by the waste compatibility DQO. Quality control tests included standards, blanks, duplicate samples, and spike recoveries.

\subsection{7 pH Analyses}

Analyses for $\mathrm{pH}$ were performed on the waste compatibility samples. Because the results were at or above the top of the accurate range for the $\mathrm{pH}$ measurement (by electrode), they should be considered estimates (Esch 1995). . Quality control tests included standards and duplicate measurements. 


\subsubsection{Hydroxide Ion Titration}

Analyses by potentiometric titration were performed directly on the waste compatibility samples, as a backup for the $\mathrm{pH}$ measurement. These analyses were performed to determine corrosion and leakage potential as described in the waste compatibility DQO. Quality control tests included standards, blanks, and duplicate measurements.

\subsubsection{Separation and Counting}

Chemical separation, followed by alpha or beta counting as appropriate, were performed directly on the waste compatibility samples. These methods were used to measure the ${ }^{239} 240 \mathrm{Pu},{ }^{241} \mathrm{Am}$, and ${ }^{90} \mathrm{Sr}$ activity of the waste. Quality control tests included standards, blanks, and duplicate measurements.

\subsubsection{Total Carbon}

Total carbon analyses by furnace oxidation were performed directly on the waste compatibility samples. Results for TIC and TOC were reported. Quality control tests included standards, blanks, duplicate measurements, and spikes (TIC only).

\subsubsection{Visual Check and Over-the-Top Radiation Measurements}

All samples were subjected to a visual check for suspended solids, clarity, and an organic layer. All samples were clear, yellow in color, and exhibited no organic layer. The over-the-top radiation measurements were as noted in Table 3-2. No formal quality control tests were performed.

\subsubsection{Percent Solids}

No measurements, either by filtering or by centrifugation, were made of the total solids because of the lack of solid material in the samples.

Table 3-4 summarizes the analytical procedure titles, instruments, and preparation methods used in the analysis of the tank 241-AN-101 samples. 
Table 3-4. Analytical Procedures. ${ }^{1}$

\begin{tabular}{|c|c|c|c|}
\hline Analysis: & Instrument: & $\begin{array}{l}\text { Preparation } \\
\text { Procedure }\end{array}$ & Procedure Number \\
\hline $\begin{array}{l}\text { Energetics by } \\
\text { DSC }\end{array}$ & $\begin{array}{l}\text { Differential scanning } \\
\text { calorimeter }\end{array}$ & \multirow[t]{13}{*}{$\begin{array}{l}\text { All analyses were } \\
\text { performed directly on } \\
\text { the liquid samples. }\end{array}$} & $\begin{array}{l}\text { LA-514-113, Rev. C-0 } \\
\text { LA-514-114, Rev. C-1 }\end{array}$ \\
\hline $\begin{array}{l}\text { Percent water by } \\
\text { TGA }\end{array}$ & $\begin{array}{l}\text { Thermal gravimetric } \\
\text { analyzer }\end{array}$ & & $\begin{array}{l}\text { LA-560-112, Rev. B-1 } \\
\text { LA-514-114, Rev. C-1 }\end{array}$ \\
\hline $\begin{array}{l}\text { Total alpha } \\
\text { activity }\end{array}$ & $\begin{array}{l}\text { Alpha proportional } \\
\text { counter }\end{array}$ & & LA-508-101, Rev. D-2 \\
\hline Specific gravity & Not applicable & & LA-510-112, Rev. C-3 \\
\hline Total metals & $\begin{array}{l}\text { Inductively coupled } \\
\text { plasma/atomic } \\
\text { emission spectrometer }\end{array}$ & & LA-505-161, Rev. B-0 \\
\hline Anions & Ion chromatograph & & LA-533-105, Rev.D-1 \\
\hline${ }^{137} \mathrm{Cs},{ }^{134} \mathrm{Cs},{ }^{60} \mathrm{Co}$ & $\begin{array}{l}\text { Gamma energy } \\
\text { analyzer }\end{array}$ & & LA-548-121, Rev. D-1 \\
\hline${ }^{90} \mathrm{Sr}$ & $\begin{array}{l}\text { Beta proportional } \\
\text { counter }\end{array}$ & & LA-220-101, Rev. D-1 \\
\hline $\mathrm{OH}^{-}$ & Potentiometric titration & & LA-211-102, Rev. C-0 \\
\hline $\mathrm{H}^{+}$ & $\mathrm{pH}$ electrode & & LA-212-106, Rev. A-0 \\
\hline TOC, TIC & Coulometric titration & & LA-622-102, Rev. C-0 \\
\hline${ }^{239 / 240} \mathrm{Pu}$ & $\begin{array}{l}\text { Alpha proportional } \\
\text { counter }\end{array}$ & & LA-943-127, Rev. B-0 \\
\hline${ }^{241} \mathrm{Am}$ & $\begin{array}{l}\text { Alpha proportional } \\
\text { counter }\end{array}$ & & LA-953-103, Rev. A-4 \\
\hline
\end{tabular}

Notes:

Rev. = revision

${ }^{1}$ Esch (1996)

${ }^{2}$ Samples for ICP. measurement were diluted in acid prior to analysis. 


\subsection{HISTORICAL SAMPLING EVENTS}

Tank 241-AN-101 was sampled several times prior to the 1995 sampling events. Because of the active process history of the tank, historical sample results no longer represent the current tank contents. Sample results from a 1993 sampling event have been included in this characterization report for informational purposes. A comparison between the 1993 results and the 1995 results was not made, however, the raw laboratory data can be found in Appendix B. 
WHC-SD-WM-ER-578 Rev. 0

This page intentionally left blank. 


\subsection{ANALYTICAL RESULTS}

This section presents the analytical results associated with the August/September and December 1995 samplings of tank 241-AN-101. The August/September 1995 event was performed to evaluate waste compatibility as defined in the waste compatibility DQO (Fowler 1995). The sampling and analysis parameters governing this event were integrated and described in the waste compatibility sampling and analysis plan (SAP) (Jones 1995). The December 1995 event was performed to evaluate safety screening criteria as defined in the safety screening DQO (Dukelow et al. 1995). The sampling and analysis parameters governing the December sampling event were integrated and described in the safety screening SAP (Benar 1995). Sample analysis was performed at the Westinghouse Hanford Company 222-S Laboratory.

Table 4-1 shows the data locations for this characterization report. Appendix A has information on the complete analytical data set. Except for TGA and DSC data, this section has information on analyte overall means only.

Table 4-1. Analytical Data Presentation Tables.

\begin{tabular}{|c|c|}
\hline (1. & Table voction \\
\hline Chemical data summary & Table 4-2 \\
\hline Thermogravimetric analysis results & Table 4-3 \\
\hline Differential scanning calorimetry results & Table 4-4 \\
\hline Headspace flammability screening results & Table 4-5 \\
\hline 1995 comprehensive analytical data & Appendix A \\
\hline
\end{tabular}

\subsection{DATA PRESENTATION}

Section 4.1 summarizes the analytical results from the two 1995 sampling events involving tank 241-AN-101. Data from the August/September 1995 analysis are reported in the 60-Day Waste Compatibility Safety Issue and Final Results for Tank 241-AN-101 Grab Samples 1AN-95-1, I-AN-95-2, and 1-AN-95-3 (Esch 1995). Data from the December 1995 analysis were reported in the Revised Final Report for Tank 241-AN-101 Grab Samples IAN-95-1 Through 1AN-95-7 (Esch 1996). Section 4.1.1 summarizes the chemical data, Section 4.1 .2 summarizes the physical data, and Section 4.1 .3 summarizes the headspace flammability results. 


\subsubsection{Chemical Data Summary}

Data from the three grab samples taken from riser 15B were combined to derive an overall mean for the three safety screening analytes: weight percent, specific gravity, and total alpha activity. Mean values for each grab sample were calculated by averaging the sample/duplicate results of each analyte, which were then used to calculate overall means. The DSC results do not require the calculation of a mean. The overall means can be found in the Appendix A tables. These values are no longer representative of the current tank contents.

Data from the three grab samples taken from riser 22A were combined to derive an overall mean for the waste compatibility analytes. The same general procedure as described above was followed. When results for 50 percent or more of the grab samples had detected results, the overall mean was reported as a detected value. Conversely, when results for more than half of the grab samples were nondetected, the overall mean was reported as a nondetected value. The overall means can be found in the Appendix $A$ tables and are used to complete Table 4-2. The overall means and the projected inventory values are no longer representative of the tank contents.

The first two columns of Table 4-2 show the analyte and overall mean. The third column shows the relative standard deviation (RSD) of the mean, defined as the standard deviation (of the mean) divided by the mean, multiplied by 100 . The RSDs were determined using analysis of variance (ANOVA) techniques. They were computed for analytes that had 50 percent or more of their values above the detection limit. For these analytes, the value of the detection limit was used in the computations. The projected inventories listed in the last column are derived by multiplying the overall mean in $\mu \mathrm{g} / \mathrm{mL}$ or $\mu \mathrm{Ci} / \mathrm{mL}$ by the estimated waste volume of $4,090 \mathrm{~kL}(1,080 \mathrm{kgal})$.

Table 4-2. Chemical Data Summary for Tank 241-AN-101. ${ }^{1}$ (2 sheets)

\begin{tabular}{|c|c|c|c|}
\hline Analyte & Overall Mean & $\begin{array}{l}\text { Relative Standard } \\
\text { Deviation (Mean) }\end{array}$ & $\begin{array}{l}\text { Projected } \\
\text { inventoms }\end{array}$ \\
\hline METAIS : & 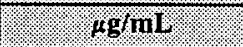 & (1:. & Kg. \\
\hline Aluminum & 20,900 & 3.5 & 85,500 \\
\hline Iron & $<20.1$ & --- & $<82.2$ \\
\hline Sodium & $1.28 \mathrm{E}+05$ & 3.0 & $5.24 \mathrm{E}+05$ \\
\hline ANIONS: & भg $\mathrm{mL}$ & 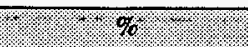 & ( \\
\hline Chloride & 3,300 & 1.0 & 13,500 \\
\hline Fluoride & 475 & 8.7 & 1,940 \\
\hline Hydroxide & 31,400 & 2.5 & $1.28 \mathrm{E}+05$ \\
\hline
\end{tabular}


Table 4-2. Chemical Data Summary for Tank 241-AN-101. ${ }^{1}$ (2 sheets)

\begin{tabular}{|c|c|c|c|}
\hline l: & Overail Mean & $\begin{array}{l}\text { Relative Standard } \\
\text { Deviation }(\text { Mean) }\end{array}$ & $\begin{array}{l}\text { Projected } \\
\text { Thentury }\end{array}$ \\
\hline ANHONS (Contud) & ugfmi. & (2): & kg \\
\hline Nitrate & 97,100 & 1.8 & $3.97 \mathrm{E}+05$ \\
\hline Nitrite & 48,200 & 2.7 & $1.97 \mathrm{E}+05$ \\
\hline Phosphate & 2,120 & 19.2 & 8,670 \\
\hline Sulfate & 3,040 & 24.5 & 12,400 \\
\hline RADIONUCUIDES & . 10 /ninl & (\%) & ( \\
\hline${ }^{241} \mathrm{Am}$ & $5.15 \mathrm{E}-05$ & 32.7 & 0.211 \\
\hline${ }^{134} \mathrm{Cs}$ & 0.00996 & 45 & \begin{tabular}{|l|}
40.7 \\
\end{tabular} \\
\hline${ }^{137} \mathrm{Cs}$ & 123 & 0.6 & $5.03 \mathrm{E}+05$ \\
\hline${ }^{60} \mathrm{Co}$ & $<0.00413$ & $\cdots$ & $<16.9$ \\
\hline${ }^{239 / 240} \mathrm{Pu}$ & $5.98 \mathrm{E}-05$ & 18.6 & 0.245 \\
\hline${ }^{90} \mathrm{Sr}$ & 0.378 & 28.3 & 1,550 \\
\hline Total alpha & $<0.00059$ & --- & $<2.41$ \\
\hline CARBON & . $14 \mathrm{~g} / \mathrm{mL}$ & 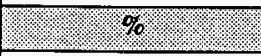 & 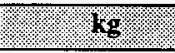 \\
\hline Total inorganic carbon & 2,450 & 2.7 & 10,000 \\
\hline Total organic carbon & $2,630(7,670)^{2}$ & 18.0 & 10,800 \\
\hline \multicolumn{4}{|c|}{ PHYSICAI PROPERTIES } \\
\hline $\mathrm{pH}$ & 13.6 & $2.3 \%$ & --- \\
\hline Water & 66.0 wt $\%$ & $0.21 \mathrm{wt} \%$ & $2.70 \mathrm{E}+06 \mathrm{~kg}$ \\
\hline Specific gravity & 1.24 & $0.58 \%$ & --- \\
\hline
\end{tabular}

Notes:

\footnotetext{
${ }^{1}$ Esch (1995 and 1996)

${ }^{2}$ Value in parentheses is the TOC dry weight result.
}

\subsubsection{Physical Data Summary}

Thermal analyses and density tests were performed on the tank 241-AN-101 grab samples to satisfy the requirements of the safety screening DQO (Dukelow et al. 1995) and the waste compatibility DQO (Fowler 1995). In addition, $\mathrm{pH}$ measurements were performed on the three waste compatibility (riser $22 \mathrm{~A}$ ) samples. 
4.1.2.1 Thermogravimetric Analysis. During TGA, the mass of a sample is measured while its temperature is increased at a constant rate. A gas, such as nitrogen or air, is passed over the sample during heating to remove any released gases. Any decrease in the weight of a sample represents a loss of gaseous matter from the sample through evaporation or through a reaction that forms gas phase products. The moisture content is estimated by assuming that all TGA sample weight loss up to a certain temperature (typically 150 to $200^{\circ} \mathrm{C}$ ) is caused by water evaporation. Weight percent water by TGA was performed by the 222-S Laboratory under a nitrogen purge using procedures LA-514-114, Rev. C-1 (Perkin-Elmer ${ }^{1}$ ), and LA-560-112, Rev. B-1 (Mettler ${ }^{2}$ ).

Table 4-3 shows the TGA results for tank 241-AN-101. All samples exhibited a large weight loss between the ambient temperature and $240^{\circ} \mathrm{C}$. Again, this weight loss is attributed to the evaporation of water. The overall percent water value for the tank from the December 1995 sampling event was 65.4 weight percent.

4.1.2.2 Differential Scanning Calorimetry. During DSC, heat absorbed or emitted by a substance is measured while the substance is exposed to a linear increase in temperature. While the substance is being heated, a gas such as nitrogen is passed over the waste material to remove any gases being released. The onset temperature for an endothermic

(characterized by or causing the absorption of heat) or an exothermic (characterized by or causing the release of heat) event is determined graphically. Analyses by DSC were performed by the 222-S Laboratory under a nitrogen atmosphere using procedure LA-514-114, Rev. C-1 (Perkin-Elmer ${ }^{\mathrm{TM}}$ ), and procedure LA-514-113, Rev.C-1 (Mettler ${ }^{\text {TM }}$ ).

Table 4-4 shows the DSC results. All reactions were endothermic; therefore, none of the samples exceeded the safety screening action limit of $-480 \mathrm{~J} / \mathrm{g}$. The peak temperature for the endothermic reactions and the magnitude of the enthalpy changes are provided for each transition. The first transition represents the endothermic reaction associated with the evaporation of free and interstitial water. For this tank, the second and third transitions probably represent the energy (heat) required to remove bound water from hydrated compounds such as aluminum hydroxide or to melt salts such as sodium nitrate. The results in Table 4-4 are on a wet weight basis. Since there were no exothermic reactions, the calculation of a 95 percent confidence interval as required by the safety screening DQO (Dukelow et al. 1995) was not necessary.

4.1.2.3 Specific Gravity. Specific gravity measurements were performed on all six grab samples using procedure LA-510-112, Rev. C-3. The analysis was performed in duplicate on direct samples-(see Table A-22 for results). . The-overall-tank specific gravity from the December 1995 sampling event was 1.22.

\footnotetext{
'Perkin-Elmer is a registered trademark of Perkins Research and Manufacturing Company, Inc., Canoga Park, California.

${ }^{2}$ Mettler is a registered trademark of Mettler Electronics, Anaheim, California.
} 
Table 4-3. Thermogravimetric Analysis Results for Tank 241-AN-101.'

\begin{tabular}{|c|c|c|c|c|c|c|}
\hline & \multicolumn{2}{|c|}{ Sample Tocation } & Temp. Range? & Resail & Duplicate & Mean \\
\hline $\begin{array}{l}\text { Sample } \\
\text { Number }\end{array}$ & Riser: & $\begin{array}{l}\text { Segment } \\
\text { Number }\end{array}$ & l. & $\%, 4,0$ & 20 11, & $9.8 \%$ \\
\hline $2408^{3}$ & \multirow[t]{3}{*}{$22 \mathrm{~A}$} & $1 \mathrm{AN}-95-1$ & $30-210(30-215)$ & 66.28 & 66.11 & 66.19 \\
\hline $2409^{3}$ & & $1 \mathrm{AN}-95-2$ & $30-215(30-215)$ & 66.27 & 65.72 & 66.00 \\
\hline $2410^{3}$ & & $1 \mathrm{AN}-95-3$ & $30-205(30-205)$ & 65.96 & 65.81 & 65.88 \\
\hline $3913^{4}$ & \multirow[t]{3}{*}{$15 \mathrm{~B}$} & $1 \mathrm{AN}-95-4$ & $35-230(35-240)$ & 65.51 & 64.93 & 65.22 \\
\hline $39414^{4}$ & & $1 \mathrm{AN}-95-5$ & $35-230(35-235)$ & 64.80 & 65.11 & 64.95 \\
\hline $3915^{3}$ & & $1 \mathrm{AN}-95-6$ & $35-215(35-210)$ & 65.95 & 66.03 & 65.99 \\
\hline \multicolumn{7}{|c|}{ Sample Weight \% Loss Mean $(\% \text { Water })^{5}=65.4 \%$} \\
\hline
\end{tabular}

Notes:

Temp. = temperature

${ }^{1}$ Esch (1995 and 1996).

${ }^{2}$ The first temperature range is for the sample result, and the range in parentheses is for the duplicate result.

${ }^{3}$ Analysis performed with Mettler ${ }^{\mathrm{TM}}$ equipment.

${ }^{4}$ Analysis performed with Perkin-Elmer ${ }^{\mathrm{TM}}$ equipment.

${ }^{5}$ Calculated with the December 1995 (15B) sample results.

4.1.2.4 pH Measurements. Measurements for $\mathrm{pH}$ were performed on the three grab samples removed from riser 22A using procedure LA-212-106, Rev. A-0. The analysis was performed in duplicate (see Table A-20 for results). The overall tank pH was 13.6. Because the results were at or above the top of the accurate range for the $\mathrm{pH}$ measurement (by electrode), they should be considered estimates (Esch 1995).

\subsubsection{Headspace Flammability Screening Results}

As requested in the safety screening SAP (Benar 1995), tank 241-AN-101 headspace was sampled and analyzed for the presence of flammable gases prior to grab sampling. Although the SAP indicated that the results were to be reported as a percent of the lower flammability limit (LFL), the instrumentation used to collect the data reported the results as a percent of the lower explosive limit (LEL). The Industrial Hygiene engineer responsible for testing 
stated that the two values were equivalent (Esch 1996). The reported LEL of 0 percent was well below the safety screening limit. In addition, the concentrations of oxygen, ammonia, and TOC vapor were determined. See Table 4-5 for the results of the combustible gas monitoring inside riser $15 \mathrm{~B}$.

Table 4-4. Differential Scanning Calorimetry Results for Tank 241-AN-101.'

\begin{tabular}{|c|c|c|c|c|c|c|c|c|c|c|}
\hline \multirow[b]{2}{*}{ Sample } & \multicolumn{2}{|c|}{ Sample } & \multirow[b]{2}{*}{ Run } & \multirow{2}{*}{$\begin{array}{l}\text { Sample } \\
\text { Weight } \\
\text { nis }\end{array}$} & \multicolumn{2}{|c|}{ Transilion 1} & \multicolumn{2}{|c|}{ mansition } & \multicolumn{2}{|c|}{ Transition 3} \\
\hline & miser & Number & & & $\begin{array}{l}\text { weal } \\
\text { geinp } \\
\text { (x) }\end{array}$ & . & 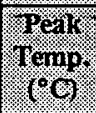 & (4) & (toris & $(1119)$ \\
\hline \multirow[t]{2}{*}{$2408^{2}$} & \multirow[t]{6}{*}{$22 \mathrm{~A}$} & \multirow[t]{2}{*}{$1 \mathrm{AN}-95-1$} & 1 & 13.49 & 116 & 1,265 & --- & --- & $\cdots$ & -- \\
\hline & & & 2 & 11.39 & 119 & 1,516 & --- & $\cdots$ & $\cdots$ & -- \\
\hline \multirow[t]{2}{*}{$2409^{2}$} & & \multirow[t]{2}{*}{$1 \mathrm{AN}-95-2$} & 1 & 12.90 & 116 & 1,606 & --- & --- & --- & -- \\
\hline & & & 2 & 15.16 & 122 & 1,891 & -- & -- & $\cdots$ & --- \\
\hline \multirow[t]{2}{*}{$2410^{2}$} & & \multirow[t]{2}{*}{$1 \mathrm{AN}-95-3$} & 1 & 16.28 & 115 & 1,303 & 243 & 6.0 & --- & -- \\
\hline & & & 2 & 17.39 & 113 & 1,255 & 243 & 6.5 & --- & -- \\
\hline \multirow[t]{2}{*}{$3913^{3}$} & \multirow[t]{6}{*}{$15 B$} & \multirow[t]{2}{*}{$1 \mathrm{AN}-95-4$} & 1 & 16.00 & 116 & 1,555 & 182 & 10.1 & 245 & 7.2 \\
\hline & & & 2 & 21.21 & 122 & 1,657 & 238 & 6.8 & --- & - \\
\hline \multirow[t]{2}{*}{$3914^{3}$} & & \multirow[t]{2}{*}{$1 \mathrm{AN}-95-5$} & 1 & 23.53 & 127 & 1,728 & 441 & 21.0 & -- & -- \\
\hline & & & 2 & 21.27 & 123 & 1,581 & 474 & 13.1 & -- & -- \\
\hline \multirow[t]{2}{*}{$3915^{2}$} & & \multirow[t]{2}{*}{$1 \mathrm{AN}-95-6$} & 1 & 14.95 & 126 & 2,005 & 242 & 29.4 & -- & $-\cdots$ \\
\hline & & & 2 & 28.00 & 140 & 1,130 & --- & --- & --- & --- \\
\hline
\end{tabular}

Notes:

$\Delta \mathrm{H}=$ change in enthalpy (negative sign denotes exothermic reaction).

'Esch (1995 and 1996)

${ }^{2}$ Analysis performed on Mettler ${ }^{\mathrm{TM}}$ equipment.

${ }^{3}$ Analysis performed on Perkin-Elmer ${ }^{\mathrm{TM}}$ equipment. 
Table 4-5. Headspace Flammability Screening for Tank 241-AN-101. ${ }^{1}$

\begin{tabular}{|l|l|}
\hline \multicolumn{1}{|c|}{ Vapor Chargateristic Measured: Results } \\
\hline Flammability vapor concentration as percent of the LEL & $0 \%$ \\
\hline Volume percent oxygen gas & $20.9 \%$ \\
\hline Concentration of ammonia gas & $40 \mathrm{ppm}$ \\
\hline Concentration of total organic carbon vapor & $1.5 \mathrm{ppm}$ \\
\hline
\end{tabular}

Note:

'Esch (1996) 
WHC-SD-WM-ER-578 Rev. 0

This page intentionally left blank. 


\subsection{INTERPRETATION OF CHARACTERIZATION RESULTS}

The purpose of this section is to discuss the overall quality and consistency of the current sampling results for tank $241-\mathrm{AN}-101$ and to assess and compare these results against historical information and program requirements.

\subsection{ASSESSMENT OF SAMPLING AND ANALYTICAL RESULTS}

This section evaluates sampling and analysis factors that may impact interpretation of the data. These factors are used to assess the overall data quality and consistency and to identify limitations in data use.

\subsubsection{Field Observations}

The safety screening DQO (Dukelow et al. 1995) requirement to sample at least two widely spaced risers was not fulfilled. An additional sampling event may be necessary to complete a safety screening assessment while satisfying the safety screening DQO requirement of obtaining samples from two risers. No problems were noted during the sampling operations. All seven samples (including the field blank) achieved 100 percent recovery.

\subsubsection{Quality Control Assessment}

The usual quality control assessment includes an evaluation of the appropriate standard recoveries, spike recoveries, duplicate analyses, and blanks that are performed in conjunction with the chemical analyses. All pertinent quality control tests were conducted on the 1995 analyses, allowing a full assessment regarding the accuracy and precision of the data. The SAPs (Benar 1995 and Jones 1995) established the specific criteria for all quality control checks. Sample and duplicate pairs exhibiting one or more quality control results outside the SAP target levels are identified (by footnoting) in Appendix A data tables.

The standard and spike recovery results provide an estimate of analysis accuracy. If a standard or spike recovery is above or below the given criterion, then the analytical results may be biased high or low, respectively. All standard recoveries were within the defined criterion. The single spikes conducted for chloride and fluoride were below the target level of 80 to 120 percent recovery... The laboratory chemist noted an.interference on the chromatogram in the region in which chloride and fluoride elute. This was most likely responsible for the poor spike recoveries. The precision (estimated by the relative percent difference, which is defined as the absolute value of the difference between the primary and duplicate samples, divided by their mean, times one hundred) between all sample pairs for all analytes was within the limits. Finally, none of the samples exceeded the criterion for preparation blanks; therefore, contamination was not a problem. 
In summary, nearly all quality control results were within the boundaries specified in the SAPs. The spike recovery difficulties with chloride and fluoride should not impact data validity or use.

\subsubsection{Data Consistency Checks}

Comparing different analytical methods can help to assess data consistency and quality. The quantity of data made it possible to compare total alpha activity to the sum of specific alpha. emitters and to calculate mass and charge balances.

5.1.3.1 Comparison of Results from Different Analytical Methods. The following data consistency check compares the results from two different analytical methods. A close correlation between the two methods strengthens the credibility of both results, whereas a poor correlation brings the reliability of the data into question.

A comparison was made between the total alpha activity mean and the sum of the means of the individual alpha emitters in Table 5-1. The sum of the activities of the individual alpha emitters was determined by adding the ${ }^{241} \mathrm{Am}$ and ${ }^{239 / 240} \mathrm{Pu}$ mean activities.

The analytical result of total alpha activity for all tank 241-AN-101 samples was below the detection limit. The sum of the alpha emitters compared well with the total alpha activity mean which is less than $0.00059 \mu \mathrm{Ci} / \mathrm{mL}$.

Table 5-1. Comparison of the Total Alpha Activity with the Sum of the Individual Activities.

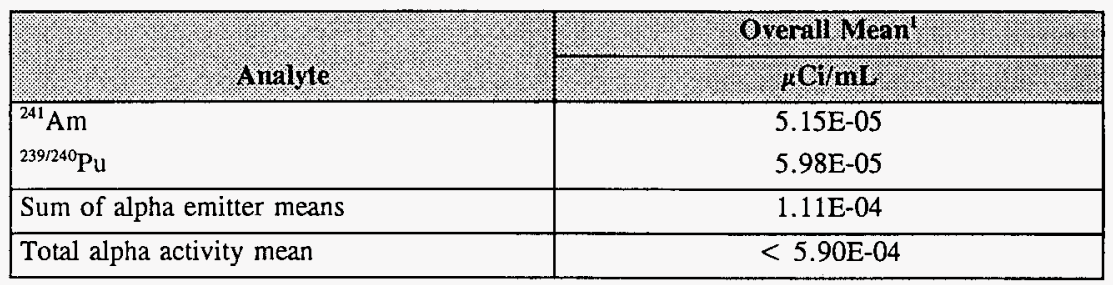

Note:

'Calculated using sample results from the August/September 1995 sampling event. 
5.1.3.2 Mass and Charge Balances. The principle objective in performing mass and charge balances is to determine whether the measurements are consistent. In calculating the balances, only analytes listed in Table 4-2, which were detected at a concentration of $1,000 \mu \mathrm{g} / \mathrm{g}$ ( 0.1 weight percent) or greater, were considered. All analytical results presented in this section were converted from $\mu \mathrm{g} / \mathrm{mL}$ to $\mu \mathrm{g} / \mathrm{g}$ (using the specific gravity mean of 1.24 ) before being used in the tables.

Sodium was the only cationic species present in detectable quantities in tank 241-AN-101 waste. However, only three metals were analyzed, which could create a low bias in the overall mass balance if an unmeasured metal were present in large quantities. This is unlikely because tank 241-AN-101 waste is entirely liquid, and most metals exist in tank waste as partially soluble or insoluble hydroxides or oxides. No solids are known to exist in tank 241-AN-101, thereby decreasing the likelihood that such metals are present.

Aluminum was assumed to be present as the aluminate anion. The acetate and carbonate values were derived from the TOC and TIC analyses, respectively. The other anionic analytes listed in Table 5-3 were assumed to be present as sodium salts and were expected to balance the positive charge exhibited by the cation. Sulfur is considered to be present as the sulfate ion, and phosphorus as the phosphate ion. Both species are assumed to be completely water soluble and appear only in the anion mass and charge calculations. The concentrations of sodium shown in Table 5-2, the anionic species shown in Table 5-3, and the percent water were ultimately used to calculate the mass balance. The uncertainty estimates (RSDs) associated with each analyte are shown in the tables. The uncertainty estimates for the cation and anion totals and the overall uncertainty shown in Table 5-4 were computed by a statistical technique known as the propagation of errors (Nuclear Regulatory Commission 1988).

The mass balance was calculated from the formula below. The 0.0001 value is the conversion factor from $\mu \mathrm{g} / \mathrm{g}$ to weight percent.

$$
\begin{aligned}
\text { Mass balance }= & \% \text { Water }+0.0001 \times\{\text { Total Analyte Concentration }\} \\
=\quad & \% \text { Water }+0.0001 \times\left\{\mathrm{Na}^{+}+\mathrm{AlO}_{2}^{-}+\mathrm{C}_{2} \mathrm{H}_{3} \mathrm{O}_{2}^{-}+\mathrm{CO}_{3}^{-2}+\mathrm{Cl}^{-}+\mathrm{OH}^{-}\right. \\
& \left.+\mathrm{NO}_{3}^{-}+\mathrm{NO}_{2}^{-}+\mathrm{PO}_{4}^{-3}+\mathrm{SO}_{4}^{-2}\right\}
\end{aligned}
$$

The total analyte concentrations calculated from the above equation is $307,000 \mu \mathrm{g} / \mathrm{g}$. The mean weight percent water obtained from thermogravimetric analysis reported in Table 4-2 is 66.0 percent, or $660,000 \mu \mathrm{g} / \mathrm{g}$. The mass balance resulting from adding the percent water to the total analyte concentration is 96.4 percent (see Table 5-4).

The following equations demonstrate the derivation of total cations and total anions, and the charge balance is the ratio of these two values. To derive the results as shown in the equations, all concentrations must first be converted to a $\mu \mathrm{g} / \mathrm{g}$ basis.

Total cations (microequivalents) $=\left[\mathrm{Na}^{+}\right] / 23.0=4,480$ microequivalents 
Total anions (microequivalents) $=\left[\mathrm{AlO}_{2}{ }^{-}\right] / 59.0+\left[\mathrm{C}_{2} \mathrm{H}_{3} \mathrm{O}_{2}{ }^{-}\right] / 59.0+\left[\mathrm{CO}_{3}^{-2}\right] / 30.0+$ $\left[\mathrm{Cl}^{-}\right] / 35.5+\left[\mathrm{OH}^{-}\right] / 17.0+\left[\mathrm{NO}_{3}^{-}\right] / 62.0+\left[\mathrm{NO}_{2}^{-}\right] / 46.0+\left[\mathrm{PO}_{4}^{-3}\right] / 31.7+\left[\mathrm{SO}_{4}^{-2}\right] / 48.1=$ 4,821 microequivalents.

The charge balance obtained by dividing the sum of the positive charge by the sum of the negative charge was 0.929 .

In summary, the above calculations yield reasonable mass and charge balance values (close to 1.00 for charge balance and $100 \%$ for mass balance) indicating that the analytical results are generally consistent.

Table 5-2. Cation Mass and Charge Data.

\begin{tabular}{|c|c|c|c|c|c|}
\hline \multirow[b]{2}{*}{ Analyte } & Concentration & \multirow{2}{*}{ Spsinimed } & $\begin{array}{l}\text { Goncentration of } \\
\text { Assunined Species }\end{array}$ & $\begin{array}{l}\mathrm{RSD} \\
\text { (Hean }\end{array}$ & Whase \\
\hline & $49 / 8$ & & 2018 & $\%$ & feags \\
\hline Sodium & 103,000 & $\mathrm{Na}^{+}$ & 103,000 & 3.0 & 4,480 \\
\hline Total & & & 103,000 & 3.0 & 4,480 \\
\hline
\end{tabular}

Table 5-3. Anion Mass and Charge Data.

\begin{tabular}{|c|c|c|c|c|c|}
\hline \multirow[b]{2}{*}{ trialyte. } & goncentratron. & \multirow{2}{*}{ Assumed } & $\begin{array}{l}\text { Concentration of } \\
\text { Assumed Species }\end{array}$ & $\begin{array}{l}\mathrm{RSD} \\
\mathrm{Mean})\end{array}$ & Giarge \\
\hline & $14 \mathrm{~g} / \mathrm{g}$ & & $48 \mathrm{~g}$ & \%. & Feors \\
\hline Aluminum & 16,900 & $\mathrm{AlO}_{2}^{-}$ & 37,000 & 3.5 & 627 \\
\hline TOC & 2,120 & $\mathrm{C}_{2} \mathrm{H}_{3} \mathrm{O}_{2}^{-}$ & 5,210 & 18.0 & 88 \\
\hline TIC & 1,980 & $\mathrm{CO}_{3}{ }^{2-}$ & 9,900 & 2.7 & 330 \\
\hline Chloride & 2,660 & $\mathrm{Cl}^{-}$ & 2,660 & 1.0 & 75 \\
\hline Hydroxide & 25,300 & $\mathrm{OH}^{-}$ & 25,300 & 2.5 & 1,490 \\
\hline Nitrate & 78,300 & $\mathrm{NO}_{3}^{-}$ & 78,300 & 1.8 & 1,260 \\
\hline Nitrite & 38,900 & $\mathrm{NO}_{2}^{-}$ & 38,900 & 2.7 & 846 \\
\hline Phosphate & 1,710 & $\mathrm{PO}_{4}{ }^{3-}$ & 1,710 & 19.2 & 54 \\
\hline Sulfate & 2,450 & $-\mathrm{SO}_{4}{ }^{2-}$ & 2,450 & 24.5 & 51 \\
\hline Total & & & 201,000 & 1.3 & 4,821 \\
\hline
\end{tabular}


Table 5-4. Mass Balance Totals.

\begin{tabular}{|l|c|c|}
\hline & Concentrations & RSD (Mean) \\
\hline Total from Table 5-2 & $\mu \mathrm{g} / \mathrm{g}$ & $\%$ \\
\hline Total from Table 5-3 & 103,000 & 3.0 \\
\hline Water \% & 201,000 & 1.3 \\
\hline Grand Total & 660,000 & 0.21 \\
\hline
\end{tabular}

\subsection{TANK WASTE PROFILE}

Six grab samples were taken during the August/September and December 1995 sampling events from risers $22 \mathrm{~A}$ and $15 \mathrm{~B}$. Three samples were collected from each riser at sample elevations identified in Table 3-2. Because three different elevations were selected in each riser, a statistical assessment of the vertical distribution of the tank waste for most analytes was possible. An assessment of the horizontal distribution of the waste for percent water and specific gravity was performed; however, the results are of limited value because the tank contents changed between sampling events.

Information on the vertical disposition of the tank contents was also available from the TLM, which indicated the waste consists entirely of supernatant. The visual descriptions of the samples from both risers were the same (clear and yellow), which, taken together with the TLM prediction, strongly implies that the tank contents were expected to be vertically homogeneous.

Waste samples were taken from three depths and from two risers. Consequently, ANOVA models with riser and/or depth terms were fit to the analytical data. The results from these models can be used to test whether or not analyte concentrations are significantly different according to the horizontal and/or vertical location.

A two-way (riser and depth) nested random effects ANOVA model was fit to the percent water and specific gravity data. For other analytes, data were available from only one riser and a one-way (depth) random effects model was fit to the results. These models ere used only for analytes with 50 percent or more of the measurements above the detection limit.

The results from the ANOVA models are used to test the significance of the riser and/or depth effect. The p-value associated with a statistical test is compared with a standard level of significance $(\alpha=0.05)$. If the p-value is less than 0.05 , there is sufficient evidence to conclude that analyte means are significantly different from each other. If the $p$-value is greater than 0.05 , there is not sufficient evidence to conclude that analyte means are different from each other. In the following paragraph, the p-values are in parentheses. 
The results from the ANOVA models indicated that there was no significant difference between risers (horizontal variability) for percent water $(0.120)$, but there were significant differences for specific gravity (0.042). There were no significant differences between depths (vertical variability) for five analytes: chloride $(0.918)$, fluoride $(0.900)$, hydroxide $(0.120),{ }^{137} \mathrm{Cs}(0.303)$, and specific gravity $(0.280)$. There were significant differences between depths for the other 13 analytes: aluminum $(0.009)$, sodium $(0.010)$, nitrate $(0.003)$, nitrite $(0.026)$, phosphate $(0.001)$, sulfate $(0.001),{ }^{241} \mathrm{Am}(0.002)$, ${ }^{239,240} \mathrm{Pu}(<0.001),{ }^{89,90} \mathrm{Sr}(<0.001)$, TIC $(0.014)$, TOC $(<0.001)$, pH $(<0.001)$, and percent water $(0.045)$. For these 13 analytes, the mean concentrations (as a function of depth, both increased and decreased.

In summary, only two analytes had horizontal information. This is insufficient to draw conclusions regarding horizontal variability. Thirteen of three 18 analytes showed significant concentration changes as a function of depth (vertical variability). However for these 13, the mean concentrations increased and decreased.

\subsection{EVALUATION OF PROGRAM REQUIREMENTS}

The three grab samples retrieved from tank 241-AN-101 in August and September 1995 were analyzed to meet the requirements of the waste compatibility DQO (Fowler 1995). The three December 1995 grab samples were analyzed in accordance with the safety screening DQO (Dukelow et al. 1995) and were to be used in conjunction with the August/September 1995 sample results to complete a safety screening assessment of tank 241-AN-101. The requirements of the waste compatibility $\mathrm{DQO}$ included all the safety screening analyses except total alpha. The total alpha analyses were later performed on the August/September archived samples.

It was discovered that waste was added to tank 241-AN-101 during September and October 1995, so a safety screening evaluation was performed with only the December 1995 sample results. Section 5.0 discusses the specific requirements of the two DQOs and a comparison of the analytical data to define concentration limits. Section 5.3.1 details the safety evaluations required by both DQOs, and Section 5.3.2 discusses the pertinent operations decision rules specified in the waste compatibility DQO.

\subsubsection{Safety Evaluation}

Data criteria-identified in the safety screening DQO are used to assure that appropriate safety issues have been identified. The waste compatibility DQO establishes criteria to assess waste compatibility for transfers into and within the double-shell tank system problems. Both DQOs investigate the same safety issues: energetics, criticality, and flammable gas accumulation. In addition, the waste compatibility DQO examines corrosion and leakage concerns. Because the safety issues of the DQOs were similar, the set of primary safety analyses required by them was also similar. 
Both DQOs requested analyses for energetics (by DSC) to evaluate the fuel content and total alpha activity to determine the criticality potential, although the specific limits set by the DQOs differed. The safety screening DQO requires the determination of the percent of the LFL of the gases in the tank headspace, while the waste compatibility DQO used specific gravity to evaluate the potential for flammable gas accumulation within the waste. In addition, the waste compatibility DQO imposes waste composition limits on the tank contents to control corrosion. For each required analysis, a notification threshold was established which, if exceeded, could warrant further investigation to assure the safety of the tank. Tables 5-5 and 5-6 list the applicable safety issues, decision variables, and thresholds for the . safety screening and waste compatibility DQOs and the mean analytical results from the 1995 grab sampling events.

For a proper safety assessment, the safety screening DQO requires vertical profiles of the waste from at least two widely-spaced risers. This requirement was not met.

The safety screening DQO has a notification limit of $480 \mathrm{~J} / \mathrm{g}$ (dry weight) for the DSC analyses (Dukelow et al. 1995). The waste compatibility DQO mandated that the value of the exotherm/endotherm ratio must be $\leq 1.0$ for any transfer to be allowed. Because no exothermic reactions were noted in any sample, neither DQO limit was exceeded, and the calculation of a 95 percent upper confidence limit (per the safety screening DQO) was unnecessary.

The potential for criticality can be assessed from the total alpha activity data. The safety screening notification limit is $1 \mathrm{~g} / \mathrm{L}$ (Dukelow et al. 1995). Because the laboratory reported total alpha activity in units of $\mu \mathrm{Ci} / \mathrm{mL}$, the $1 \mathrm{~g} / \mathrm{L}$ threshold was converted to $61.5 \mu \mathrm{Ci} / \mathrm{mL}$ using the formula in footnote 1 , Table $5-5$. The calculated overall mean, based on the nondetected results, was $<0.00147 \mu \mathrm{Ci} / \mathrm{mL}$, well below the $61.5 \mu \mathrm{Ci} / \mathrm{mL}$ safety screening DQO limit. Because total alpha activity was not detected in any sample, the statistical calculation of a 95 percent upper confidence limit was unnecessary. The waste compatibility DQO limit for total alpha activity was $\leq 0.05 \mathrm{~g} / \mathrm{gal}$. This converts to $0.812 \mu \mathrm{Ci} / \mathrm{mL}$ (using the ${ }^{239} \mathrm{Pu}$ specific activity of $0.0615 \mathrm{Ci} / \mathrm{g}$ ), which was almost a factor of three above the estimated analytical result (see Table 5-6).

The flammability of the gas in the tank headspace is the final safety screening DQO consideration. According to the DQO, any flammable gas present must be $\leq 25$ percent of the LFL. The analytical result was 0 percent of the LEL, which is equivalent to 0 percent of the LFL (see Section 4.1.3). The waste compatibility DQO flammable gas decision rule requires that the specific gravity of the waste be $<1.3$ before any transfer is allowed. The analytical result of 1.24 was below.this limit.

The waste compatibility DQO also specifies several waste composition limits to control corrosion; these are listed in Table 5-6. The analytical results from the 1995 grab samples for hydroxide, nitrate, and nitrite all met the criteria listed. 
Table 5-5. Decision Variables and Criteria for the Safety Screening Data Quality Objective.

\begin{tabular}{|c|c|c|c|}
\hline Shatery ssue. & Primary Decision & Wocision griteria & Mean inalutical \\
\hline Ferrocyanide/Organics & Total fuel content & $480 \mathrm{~J} / \mathrm{g}$ & No exotherms \\
\hline Criticality & Total alpha activity & $1 \mathrm{~g} / \mathrm{L}^{2}(61.5 \mu \mathrm{Ci} / \mathrm{mL})$ & $\begin{array}{l}<0.00147 \\
\mu \mathrm{Ci} / \mathrm{mL}\end{array}$ \\
\hline Flammable gas & Flammable gas & $25 \%$ of the LFL & 0 percent LEL \\
\hline
\end{tabular}

Notes:

${ }^{\mathrm{t}}$ December 1995 sampling event.

${ }^{2}$ Although the actual decision criterion listed in the DQO was $1 \mathrm{~g} / \mathrm{L}$, total alpha was measured in ${ }_{\mu} \mathrm{Ci} / \mathrm{mL}$ rather than $\mathrm{g} / \mathrm{L}$. To convert the notification limit for total alpha into the same units as the laboratory, it was assumed that all alpha decay originated from ${ }^{239} \mathrm{Pu}$. Using the specific activity of ${ }^{239} \mathrm{Pu}(0.0615 \mathrm{Ci} / \mathrm{g})$, the decision criterion may be converted to $61.5 \mu \mathrm{Ci} / \mathrm{mL}$ as shown:

$$
\left(\frac{1 \mathrm{~g}}{\mathrm{~L}}\right)\left(\frac{1 \mathrm{~L}}{10^{3} \mathrm{~mL}}\right)\left(\frac{0.0615 \mathrm{Ci}}{1 \mathrm{~g}}\right)\left(\frac{10^{6} \mu \mathrm{Ci}}{1 \mathrm{Ci}}\right)=61.5 \frac{\mu \mathrm{Ci}}{\mathrm{mL}}
$$

Table 5-6. Decision Variables and Criteria for the Waste Compatibility Data Quality Objective.

\begin{tabular}{|c|c|c|c|}
\hline Sarety lssue & $\begin{array}{l}\text { Primary Decision } \\
\text { Variable }\end{array}$ & $\begin{array}{l}\text { Decision Griterla } \\
\text { Thresliold }\end{array}$ & $\begin{array}{l}\text { Mean A milytical } \\
\text { Result }\end{array}$ \\
\hline Energetics & Total fuel content & Exotherm/endotherm ratio $<1.0$ & No exotherms \\
\hline Criticality & $\begin{array}{l}\text { Total alpha } \\
\text { activity }\end{array}$ & $0.05 \mathrm{~g} / \mathrm{gal}(0.812 \mu \mathrm{Ci} / \mathrm{mL})$ & $\begin{array}{l}<0.00147 \\
\mu \mathrm{Ci} / \mathrm{mL}\end{array}$ \\
\hline $\begin{array}{l}\text { Flammable gas } \\
\text { accumulation }\end{array}$ & $\begin{array}{l}\text { Waste-specific } \\
\text { gravity }\end{array}$ & $<1.3$ & 1.24 \\
\hline Corrosion & $\begin{array}{l}\text { Concentration of } \\
\text { hydroxide, } \\
\text { nitrate, and nitrite }\end{array}$ & $\begin{array}{l}1.0 \underline{\mathrm{M}}<\left[\mathrm{NO}_{3}^{-}\right] \leq 3.0 \underline{\mathrm{M}} \\
0.1 \times\left[\mathrm{NO}_{3}^{-}\right] \leq\left[\mathrm{OH}^{-}\right]<10.0 \mathrm{M} ; \\
{\left[\mathrm{OH}^{-}\right]+\left[\mathrm{NO}_{2}^{-}\right] \geq 0.4 \times\left[\mathrm{NO}_{3}^{-}\right]}\end{array}$ & $\begin{array}{l}{\left[\mathrm{NO}_{3}^{-}\right]=1.57 \underline{\mathrm{M}}} \\
{\left[\mathrm{OH}^{-}\right]=1.85 \underline{\mathrm{M}}} \\
{\left[\mathrm{NO}_{2}^{-}\right]=1.05 \underline{\mathrm{M}}}\end{array}$ \\
\hline
\end{tabular}

Note:

${ }^{1}$ August/September 1995 sampling event. 
Another factor in assessing tank safety is the heat generation and temperature of the waste. Heat is generated in tanks from radioactive decay; therefore the tank heat load can be calculated from radionuclide data. An estimate of $2,380 \mathrm{~W}(8,120 \mathrm{Btu} / \mathrm{hr}$ ) was derived (see Table 5-7). For comparison, the HTCE estimate of heat load was $102 \mathrm{~W}$ (349 Btu/hr). The HTCE prediction is low because the ${ }^{137} \mathrm{Cs}$ was underestimated. Both heat load values are well below the 70,000 Btu/hr operating specification limit (Harris 1994).

Because an upper temperature limit has been exhibited (see Section 2.4.2), it may be concluded that any heat generated from radioactive sources throughout the year is dissipated. .

Table 5-7. Tank 241-AN-101 Projected Heat Load.

\begin{tabular}{|c|c|c|c|}
\hline Radioniclide & fCimL & (9i & \\
\hline${ }^{241} \mathrm{Am}$ & $5.15 \mathrm{E}-05$ & 0.211 & 0.00692 \\
\hline${ }^{134} \mathrm{Cs}$ & 0.00996 & 40.7 & 0.415 \\
\hline${ }^{137} \mathrm{Cs}$ & 123 & $5.03 \mathrm{E}+05$ & 2,370 \\
\hline 每 $\mathrm{Co}$ & $<0.00413$ & $<16.9$ & $<0.260$ \\
\hline${ }^{239 / 240} \mathrm{Pu}$ & $5.98 \mathrm{E}-05$ & 0.245 & 0.00747 \\
\hline${ }^{89 / 90} \mathrm{Sr}$ & 0.378 & 1,550 & 10.4 \\
\hline Total & & $5.05 \mathrm{E}+05$ & 2,380 \\
\hline
\end{tabular}

\subsubsection{Operations Decision Rules Evaluation}

The waste compatibility program requires a formal operations analysis of nonroutine transfers before they are approved. Several criteria are applicable when evaluating the feasibility of a waste transfer between tanks (see Table 5-8). The criteria address three operations issues: segregating waste, avoiding excess heat generation, and ensuring that the source waste can be pumped to the receiving tank (Fowler 1995).

The TRU waste segregation rule is addressed by determining the TRU concentration of the source waste. If the source waste has a TRU concentration $\geq 0.1 \mu \mathrm{Ci} / \mathrm{g}$, the waste is transferred to a TRU storage tank; otherwise, it is sent to a non-TRU tank, or a technical evaluation is prepared demonstrating that TRU segregation will not be jeopardized. The tank 241-AN-101 TRU concentration of $9.05 \mathrm{E}-05 \mu \mathrm{Ci} / \mathrm{g}$ was derived by summing the measured ${ }^{241} \mathrm{Am}$ and ${ }^{239 / 240} \mathrm{Pu}$ activity means. This value is well below the TRU threshold.

The complexant waste segregation rule is addressed by determining the TOC of the source waste at the double-shell slurry feed composition. This is done by running several parameters, including the source waste TOC, into a computer program that simulates concentrating the waste to double-shell slurry feed composition. When the desired concentration has been reached, the TOC is compared to $10 \mathrm{~g} / \mathrm{L}$. If the TOC exceeds this 
limit, the waste is segregated with complexed waste. If the TOC is less than $10 \mathrm{~g} / \mathrm{L}$, the waste may be segregated with noncomplexed waste. The tank 241-AN-101 TOC analytical result is $2,630 \mu \mathrm{g} / \mathrm{mL}$.

The heat generation threshold depends on the operating specification document limit for a given tank. The heat generation limit for tank $241-\mathrm{AN}-101$ is $20,500 \mathrm{~W}(70,000 \mathrm{Btu} / \mathrm{hr})$ (Harris 1994). The heat load was calculated at 2,380 W $(8,120 \mathrm{Btu} / \mathrm{hr})$, far below the limit.

Table 5-8. Waste Compatibility Operations Decision Rules.

\begin{tabular}{|c|c|c|c|}
\hline $\begin{array}{l}\text { Operations: } \\
\text { Issue }\end{array}$ & $\begin{array}{l}\text { Primary Decision } \\
\text { Yaquable-s. }\end{array}$ & $\begin{array}{l}\text { Decision C Giterial } \\
\text { Thresholo: }\end{array}$ & $\begin{array}{l}\text { Mean A Arilytical Result } \\
\text { or Sowroe Waste }\end{array}$ \\
\hline Transuranics & TRU elements & {$[\mathrm{TRU}] \leq 0.1 \mu \mathrm{Ci} / \mathrm{g}$} & $9.05 \mathrm{E}-05 \mu \mathrm{Ci} / \mathrm{g}$ \\
\hline Heat load & $\begin{array}{l}\text { Heat generation rate of } \\
\text { source waste plus that of } \\
\text { waste in the receiving tank. }\end{array}$ & $\begin{array}{l}20,500 \mathrm{~W} \\
(70,000 \mathrm{Btu} / \mathrm{hr})\end{array}$ & $\begin{array}{l}2,380 \mathrm{~W} \\
(8,120 \mathrm{Btu} / \mathrm{hr})\end{array}$ \\
\hline \multicolumn{3}{|c|}{ Pipe plugging and waste viscosity } & $\begin{array}{l}\text { not applicable to this } \\
\text { document }\end{array}$ \\
\hline Organics & $\begin{array}{l}\text { TOC of the double-shell } \\
\text { slurry feed }\end{array}$ & $10,000 \mu \mathrm{g} / \mathrm{mL}^{1}$ & $2,630 \mu \mathrm{g} / \mathrm{mL}$ \\
\hline
\end{tabular}

Note:

${ }^{1}$ Comparison made on a wet weight basis per the DQO (Fowler 1995). 


\subsection{CONCLUSIONS AND RECOMMENDATIONS}

Tank 241-AN-101 was grab sampled in August/September and December 1995. The August/September sampling event was performed to evaluate the waste for compatibility issues in accordance with Data Quality Objectives for the Waste Compatibility Program (Fowler 1995). The December sampling event was performed to provide sample results from a second riser as required by the Tank Safety Screening Data Quality Objective (Dukelow et al. 1995) so that a safety screening assessment of the tank could be completed. The sampling and analysis of the December grab samples were performed as mandated in the safety screening DQO. Because the total alpha analyses were not required for the August/September sampling event, they were later performed on the archived August/September 1995 samples.

A safety screening evaluation for tank 241-AN-101 was performed with only the December 1995 sample results, which were from one riser. It was discovered that tank AN-101 received waste from saltwell liquid pumping and an unknown source in September and October 1995. Because the tank contents changed during the time between sampling events, the sample results from riser 22A (August/September 1995 sampling event) were not used. An additional sampling may be necessary to complete a safety screening assessment of tank 241-AN-101 while fulfilling the requirement of obtaining samples from two risers.

Comparisons were made between the analytical results and the decision criteria of the safety screening and waste compatibility DQOs. All analytical results satisfied the DQO criteria. No exothermic reactions were observed in any samples. The total alpha activity mean of $<0.00147 \mu \mathrm{Ci} / \mathrm{mL}$ was well below the safety screening limit of $61.5 \mu \mathrm{Ci} / \mathrm{mL}$ and the $0.05 \mathrm{~g} / \mathrm{gal}$ waste compatibility safety limit, and the TRU content of $9.05 \mathrm{E}-05 \mu \mathrm{Ci} / \mathrm{g}$ was below the waste compatibility operations limit of $0.1 \mu \mathrm{Ci} / \mathrm{g}$. The flammable gas concentration in the tank headspace was found to be 0 percent of the LEL, and the waste specific gravity was 1.24 , below the waste compatibility safety limit of 1.3 for the flammable gas accumulation issue.

The requirements for the remaining waste compatibility issues, corrosion, and heat load also were satisfied. The concentrations of $\mathrm{NO}_{3}{ }^{-}, \mathrm{OH}^{-}$, and $\mathrm{NO}_{2}^{-}$were within their prescribed boundaries. The tank heat load calculated from radionuclide data was $2,380 \mathrm{~W}(8,120$ $\mathrm{Btu} / \mathrm{hr})$, less than the operating specification limit of $20,500 \mathrm{~W}(70,000 \mathrm{Btu} / \mathrm{hr})$. 
WHC-SD-WM-ER-578 Rev. 0

This page intentionally left blank. 


\subsection{REFERENCES}

Agnew, S. F., 1995, Hanford Defined Wastes: Chemical and Radionuclide Compositions, LA-UR-94-2657, Rev, 2, Los Alamos National Laboratory, Los Alamos, New Mexico.

Agnew, S. F., P. Baca, R. A. Corbin, K. A. Jurgensen, and B. Young, 1995, Tank Layer Model (TLM), LA-UR-94-4269, Rev. 1, Los Alamos National Laboratory, Los Alamos, New Mexico.

Agnew, S. F., R. A. Corbin, T. B. Duran, K. A. Jurgensen, T. P. Ortiz, and B. L. Young, 1996, Waste Status and Transaction Record Summary for the Southeast Quadrant of the Hanford 200 Area, WHC-SD-WM-TI-689, Rev. 1, Westinghouse Hanford Company, Richland, Washington.

Alstad, A. T., 1992, Riser Configuration Document for Double-Shell Waste Tanks, WHC-SD-RE-TI-093, Rev. 3, Westinghouse Hanford Company, Richland, Washington.

Benar, C. J., 1995, Tank 241-AN-101 Grab Sampling and Analysis Plan, WHC-SD-WM-TSAP-037, Rev. 0A, Westinghouse Hanford Company, Richland, Washington.

Brevick, C. H., L. A. Gaddis, W. W. Pickett, 1995a, Historical Tank Content Estimate for the Southeast Quadrant of the Hanford 200 Areas, WHC-SD-WM-ER-350, Rev. 0 , ICF Kaiser Hanford Company, Richland, Washington.

Brevick, C. H., L. A. Gaddis, S. D. Consort, 1995b, Supporting Document for the Southeast Quadrant Historical Tank Content Estimate Report for AN Tank Farm, WHC-SD-WM-ER-314, Rev. 0, ICF Kaiser Hanford Company, Richland, Washington.

Carothers, K. G., 1994, Data Quality Objectives for the Waste Compatibility Program, WHC-SD-WM-DQO-001, Rev. 0, Westinghouse Hanford Company, Richland, Washington.

DeLorenzo, D.S., A.T. DiCenso, D.B. Hiller, K.W. Johnson, J.H. Rutherford, D.J. Smith, and B.C. Simpson, 1994, Tank Characterization.Reference Guide, WHC-SD-WM-TI-648, Rev. 0, Westinghouse Hanford Company, Richland, Washington.

Dukelow, G. T., J. W. Hunt, H. Babad, and J. E. Meacham, 1995, Tank Safety Screening Data Quality Objective, WHC-SD-WM-SP-004, Rev. 2, Westinghouse Hanford Company, Richland, Washington. 
Ecology, EPA, and DOE, 1996, Hanford Federal Facility Agreement and Consent Order, as amended, Washington State Department of Ecology, U.S. Environmental Protection Agency, and U.S. Department of Energy, Olympia, Washington.

Esch, R., 1995, 60-Day Waste Compatibility Safery Issue and Final Results for Tank 241-AN-101, Grab Samples 1AN-95-1, 1AN-95-2, and 1AN-95-3, WHC-SD-WM-DP-148, Rev. 0, Westinghouse Hanford Company, Richland, Washington.

Esch, R., 1996, Revised Final Report for Tank 241-AN-101, Grab Samples 1AN-95-1 through IAN-95-7, WHC-SD-WM-DP-148, Rev. 1, Westinghouse Hanford Company, Richland, Washington.

Fowler, K. D, 1995, Data Quality Objectives for the Waste Compatibility Program, WHC-SD-WM-DQO-001, Rev. 1, Westinghouse Hanford Company, Richland, Washington.

Hanlon, B. M., 1996, Waste Tank Summary Report for Month Ending December 31, 1995, WHC-EP-0182-93, Westinghouse Hanford Company, Richland, Washington.

Harris, J.P., 1994, Unclassified Operating Specifications for the 241-AN,AP,AW, AY,AZ, \& SY Tank Farms, OSD-T-151-00007, Rev. H-8, Westinghouse Hanford Company, Richland, Washington.

Jones, J. M., 1995, Compatibility Grab Sampling Analysis Plan, WHC-SD-WM-TSAP-037, Rev. 1, Westinghouse Hanford Company, Richland, Washington.

Nuclear Regulatory Commission, 1988, Statistical Methods for Nuclear Materials Management, NUREG-CR-4604, PNL-5849, C. A. Bennett and W. M. Bowen (eds.), U.S. Government Printing Office, Washington, D.C., 20013-7082.

Sutey, M. J., 1993, "Waste Compatibility Assessment of Tank 241-AN-101 with Tanks 241-BX-110 and 241-BX-111," (Internal Memo 7C242-93-029 to S. D. Godfrey, August 3), Westinghouse Hanford Company, Richland, Washington.

Vitro Engineering Corporation, 1987, "Plan Tank Penetrations 241-AN Tanks," Drawing No. H-2-71976, Rev. 5, ICF Kaiser Hanford, Richland, Washington.

WHC, 1992, "Riping Plan Tank AN-101,... Drawing No..H-2-71991, Rev. 9, Westinghouse Hanford Company, Richland, Washington. 
WHC-SD-WM-ER-578 Rev. 0

APPENDIX A

ANALYTICAL RESULTS FROM 1995 GRAB SAMPLING EVENTS

A-1 
WHC-SD-WM-ER-578 Rev. 0

This page intentionally left blank. 


\section{A.0 ANALYTICAL RESULTS FROM 1995 GRAB SAMPLING EVENTS}

\section{A.1 INTRODUCTION}

Appendix A presents the tank 241-AN-101 chemical, radiochemical, and physical data in table form and in terms of the specific concentrations of metals, ions, radionuclides, and physical properties.

Each data table lists the following: Labcore sample identification, sample origin (riser and grab sample numbers), an original and duplicate result for each sample, a sample mean, a mean for the tank in which all grab samples are weighted equally, an RSD of the mean, and a projected tank inventory for the particular analyte using the overall mean and the estimated waste volume $(4,090 \mathrm{~kL})$. The projected tank inventory column is not applicable for the $\mathrm{pH}$, percent water, or specific gravity data. The data are listed in standard notation for values greater than 0.001 and less than 100,000 . Values outside these limits are listed in scientific notation.

The tables are numbered A-1 through A-22. A description of the units and symbols used in the analyte tables and the references used in compiling the analytical data (Esch 1995 and 1996) are found in the List of Terms and Section 7.0, respectively. For information on sampling rationale, locations, and descriptions of sampling events, see Section 3.0.

\section{A.2 ANALYTE TABLE DESCRIPTION}

The "Labcore Sample Number" column lists the laboratory sample for which the analyte was measured. Only the last four digits of each sample number are included in the tables because the first six digits are repetitive for all samples ( 95 T00___ Column two lists the riser from which the sample was obtained, and column three specifies the particular grab sample.

The "Result" and "Duplicate" columns are self-explanatory. The "Mean" column is the average of the result and duplicate values. All values, including those below the detection level (indicated by a less-than symbol, <), were averaged in calculating the sample means. If the result and duplicate values were both nondetected, the mean is expressed as a nondetected value. If one of the two values is nondetected, and one or both are detected, then the sample mean is reported as a detected value. The result and duplicate values and the result/duplicate means, are reported in the tables exactly as found in the original laboratory data package. The means may appear to have been rounded up in some cases and rounded down in others. This is because the analytical results in the tables may have fewer significant figures than originally reported, not because the means were incorrectly calculated. 
The overall (or analyte concentration) means for the waste in tank 241-AN-101 were calculated as follows:

Grab sample mean: The arithmetic mean within a grab sample was calculated by averaging the result and duplicate values.

Riser mean (applicable only to the total alpha activity, percent water, and specific gravity data): For each of the two risers, the riser mean was calculated by averaging the three grab sample means.

Overall mean: The overall mean was calculated by averaging the two riser means for total alpha activity, percent water, and specific gravity. For other analytes, the overall mean was derived by averaging the three result/duplicate means.

The RSD of the mean (in percent) is 100 times the standard deviation of the mean divided by the overall tank mean. Relative standard deviations of the mean were not computed for analytes that had greater than 50 percent nondetected values. The standard deviation of the mean was estimated using standard ANOVA statistical techniques and used all data available for a given analyte.

The projected inventory is the product of the overall mean and the estimated volume of tank waste $(4,090 \mathrm{~kL})$ and the appropriate conversion factors.

The four quality control parameters assessed on the tank 241-AN-101 samples were standards, spikes, duplicates, and blanks. The quality control results were summarized in Section 5.1.2. The only quality control parameters outside their target level were the low spike results for chloride and fluoride. The sample and duplicate pairs for these two analytes are footnoted in their respective tables. 
Table A-1. Tank 241-AN-101 Analytical Results: Aluminum.

\begin{tabular}{|c|c|c|c|c|c|c|c|c|}
\hline Gabcore & Rles. & Grab. & Result & Buplicate & Mean & $\begin{array}{l}\text { Orerall } \\
\text { Mean }\end{array}$ & $\begin{array}{l}\text { RSD } \\
\text { Mean) }\end{array}$ & $\begin{array}{l}\text { Projected } \\
\text { Inventory }\end{array}$ \\
\hline Nuinber & Nuniber & Number & ogline & 19/mi & $8 \mathrm{~g} / \mathrm{mL}$ & $19 / \mathrm{mi}$ & $8 \%$ & $k_{8}$ \\
\hline 2408 & $22 \mathrm{~A}$ & $1 \mathrm{AN}-95-1$ & 22,200 & 21,900 & 22,000 & \multirow[t]{3}{*}{20,900} & \multirow[t]{3}{*}{3.5} & \multirow[t]{3}{*}{85,500} \\
\hline 2409 & $22 \mathrm{~A}$ & $1 \mathrm{AN}-95-2$ & 19,600 & 19,500 & 19,500 & & & \\
\hline 2410 & $22 \mathrm{~A}$ & $1 \mathrm{AN}-95-3$ & 20,800 & 21,500 & 21,200 & & & \\
\hline
\end{tabular}

Table A-2. Tank 241-AN-101 Analytical Results: Iron.

\begin{tabular}{|c|c|c|c|c|c|c|c|c|}
\hline Labcore & $\mathrm{R} / \mathrm{cer}$ & Grab & Result & Duplicate & Mean & overal & $\begin{array}{l}\text { RSD } \\
\text { mean }\end{array}$ & $\begin{array}{l}\text { Projected } \\
\text { Inventory }\end{array}$ \\
\hline Nuinber & Number & Number & $4 \mathrm{~g} / \mathrm{mL}$ & $4 \mathrm{~g} / \mathrm{mll}$ & $/ 8 \mathrm{~g} / \mathrm{mL}$ & $x \mathrm{dml}$ & $9 \%$ & $18 \mathrm{~g}$ \\
\hline 2408 & $22 \mathrm{~A}$ & $1 \mathrm{AN}-95-1$ & $<20.05$ & $<20.05$ & $<20.05$ & \multirow[t]{3}{*}{$<20.1$} & \multirow[t]{3}{*}{---} & \multirow[t]{3}{*}{$<82.2$} \\
\hline 2409 & $22 \mathrm{~A}$ & $1 \mathrm{AN}-95-2$ & $<20.05$ & $<20.05$ & $<20.05$ & & & \\
\hline 2410 & $22 \mathrm{~A}$ & $1 \mathrm{AN}-95-3$ & $<20.05$ & $<20.05$ & $<20.05$ & & & \\
\hline
\end{tabular}


Table A-3. Tank 241-AN-101 Analytical Results: Sodium.

\begin{tabular}{|c|c|c|c|c|c|c|c|c|}
\hline Sannle & Riser: & Grabt & Result & Duplicate & $18 \mathrm{Mean}$ & $\begin{array}{l}\text { Overall } \\
\text { vean }\end{array}$ & $\begin{array}{l}\text { RSD } \\
\text { Mean }\end{array}$ & $\begin{array}{l}\text { Projected } \\
\text { Inventory }\end{array}$ \\
\hline Number & Thimber & Number & ig/mi & $\mu \mathrm{g} / \mathrm{mL}$ & $4 \mathrm{~g} / \mathrm{mi}$ & $14 \mathrm{~g} / \mathrm{ml}$ & .8 & Kg \\
\hline 2408 & $22 \mathrm{~A}$ & $1 \mathrm{AN}-95-1$ & $1.24 \mathrm{E}+05$ & $1.23 \mathrm{E}+05$ & $1.23 E+05$ & \multirow[t]{3}{*}{$1.28 \mathrm{E}+05$} & \multirow[t]{3}{*}{3.0} & \multirow[t]{3}{*}{$5.24 \mathrm{E}+05$} \\
\hline 2409 & $22 \mathrm{~A}$ & $1 \mathrm{AN}-95-2$ & $1.26 \mathrm{E}+05$ & $1.25 \mathrm{E}+05$ & $1.25 \mathrm{E}+05$ & & & \\
\hline 2410 & $22 \mathrm{~A}$ & $1 \mathrm{AN}-95-3$ & $1.34 \mathrm{E}+05$ & $1.38 \mathrm{E}+05$ & $1.36 \mathrm{E}+05$ & & & \\
\hline
\end{tabular}

Table A-4. Tank 241-AN-101 Analytical Results: Chloride.

\begin{tabular}{|c|c|c|c|c|c|c|c|c|}
\hline Labcore & Riser & Graib & Resilt & Duplicate & Vean & $\begin{array}{l}\text { Orerail } \\
\text { Mean }\end{array}$ & $\frac{\mathrm{RSD}}{\mathrm{Meqn}}$ & $\begin{array}{l}\text { Projected } \\
\text { inventory }\end{array}$ \\
\hline Number & Number & Number. & $4 \mathrm{~g} / \mathrm{ml}$ & $18 \mathrm{~g} / \mathrm{mil}$ & $49 / \mathrm{ml}$ & $4 \mathrm{~g} / \mathrm{ml}$ & (. & 148 \\
\hline 2408 & $22 \mathrm{~A}$ & $1 \mathrm{AN}-95-1$ & 3,300 & 3,260 & $3,280^{1}$ & \multirow[t]{3}{*}{3,300} & \multirow[t]{3}{*}{2.7} & \multirow[t]{3}{*}{13,500} \\
\hline 2409 & $22 \mathrm{~A}$ & $1 \mathrm{AN}-95-2$ & 3,300 & 3,230 & 3,260 & & & \\
\hline 2410 & $22 \mathrm{~A}$ & $1 \mathrm{AN}-95-3$ & 3,040 & 3,700 & 3,370 & & & \\
\hline
\end{tabular}

Note:

'The spike recovery was below the 80 to 120 percent recovery range defined in the SAP. 
Table A-5. Tank 241-AN-101 Analytical Results: Fluoride.

\begin{tabular}{|c|c|c|c|c|c|c|c|c|}
\hline Sabcore & Riser. & Grab & Result & Duplicate & Mean & $\begin{array}{l}\text { Overall } \\
\text { Vean }\end{array}$ & $\begin{array}{l}\text { RSD } \\
(\mathrm{Mean})\end{array}$ & $\begin{array}{l}\text { Projected } \\
\text { Inventory }\end{array}$ \\
\hline Number & Niniber & Number & $4 \mathrm{~g} / \mathrm{mL}$ & $4 \mathrm{~g} / \mathrm{ml}$ & $148 \mathrm{mil}$ & $6 \mathrm{grni}$ & $\%$ & kg \\
\hline 2408 & $22 \mathrm{~A}$ & 1 AN-95-1 & $<68.9$ & 817.0 & $443.0^{1}$ & \multirow[t]{3}{*}{475} & \multirow[t]{3}{*}{21.2} & \multirow[t]{3}{*}{1,940} \\
\hline 2409 & $22 \mathrm{~A}$ & $1 \mathrm{AN}-95-2$ & 604.0 & 510.0 & 557.0 & & & \\
\hline 2410 & $22 \mathrm{~A}$ & $1 \mathrm{AN}-95-3$ & 425.0 & 423.0 & 424.0 & & & \\
\hline
\end{tabular}

Note:

'The spike recovery was below the 80 to 120 recovery range specified in the SAP.

Table A-6. Tank 241-AN-101 Analytical Results: Hydroxide.

\begin{tabular}{|c|c|c|c|c|c|c|c|c|}
\hline Labcore & Riser & Grab & Result & Duplicate & Mean & $\begin{array}{l}\text { Orerall } \\
\text { Mean }\end{array}$ & (MSAD) & $\begin{array}{l}\text { Projected } \\
\text { mventory }\end{array}$ \\
\hline Number & Number & Numiber & Hg/ml & $08 \mathrm{~min}$ & $r \mathrm{~g} / \mathrm{mL}$ & $49 / \mathrm{ml}$ & $\%$ & kg. \\
\hline 2408 & $22 \mathrm{~A}$ & $1 \mathrm{AN}-95-1$ & 30,800 & 30,000 & 30,400 & \multirow[t]{3}{*}{31,400} & \multirow[t]{3}{*}{2.5} & \multirow[t]{3}{*}{$1.28 \mathrm{E}+05$} \\
\hline 2409 & $22 \mathrm{~A}$ & $1 \mathrm{AN}-95-2$ & 32,200 & 33,700 & 33,000 & & & \\
\hline 2410 & $22 \mathrm{~A}$ & $1 \mathrm{AN}-95-3$ & 30,100 & 31,500 & 30,800 & & & \\
\hline
\end{tabular}


Table A-7. Tank 241-AN-101 Analytical Results: Nitrate.

\begin{tabular}{|c|c|c|c|c|c|c|c|c|}
\hline $\begin{array}{l}\text { Labcore } \\
\text { Sample }\end{array}$ & Riser & $\begin{array}{l}\text { Grab } \\
\text { Sample }\end{array}$ & Resuilt & Diplicate & Mean & $\begin{array}{l}\text { Oyeral } \\
\text { Mear }\end{array}$ & $\begin{array}{l}\text { RSD } \\
\text { (Neam) }\end{array}$ & $\begin{array}{l}\text { Projected } \\
\text { Invenitory }\end{array}$ \\
\hline Number & Number & Number & $14 \mathrm{~g} / \mathrm{ml}$ & $18 \mathrm{mil}$ & Ag/mi. & agfint & $4 \%$ & lsg. \\
\hline 2408 & $22 \mathrm{~A}$ & $1 \mathrm{AN}-95-1$ & 96,500 & 97,700 & 97,100 & \multirow[t]{3}{*}{97,100} & \multirow[t]{3}{*}{1.8} & \multirow[t]{3}{*}{$3.97 E+05$} \\
\hline 2409 & $22 \mathrm{~A}$ & $1 A N-95-2$ & $1.00 \mathrm{E}+05$ & $1.00 \mathrm{E}+05$ & $1.00 \mathrm{E}+05$ & & & \\
\hline 2410 & $22 \mathrm{~A}$ & $1 \mathrm{AN}-95-3$ & 94,200 & 94,000 & 94,100 & & & \\
\hline
\end{tabular}

Table A-8. Tank 241-AN-101 Analytical Results: Nitrite.

\begin{tabular}{|c|c|c|c|c|c|c|c|c|}
\hline \multirow{2}{*}{$\begin{array}{l}\text { Labcore } \\
\text { Sample } \\
\text { Number }\end{array}$} & \multirow{2}{*}{ Number } & \multirow{2}{*}{$\begin{array}{l}\text { Grab } \\
\text { Sample } \\
\text { Number }\end{array}$} & Result & Duplicate & Mean & $\begin{array}{l}\text { Oreral } \\
\text { Mean }\end{array}$ & $\begin{array}{l}\text { RSD } \\
\text { (Mean) }\end{array}$ & $\begin{array}{l}\text { Projected } \\
\text { Inventory }\end{array}$ \\
\hline & & & $\mu \mathrm{g} / \mathrm{mL}$ & tg/nil. & $10 \mathrm{~g} / \mathrm{ml}$ & $4 \mathrm{~g} / \mathrm{mL}$ & $1 \% \%$ & $.1 \mathrm{~kg}$. \\
\hline 2408 & $22 \mathrm{~A}$ & $1 A N-95-1$ & 48,400 & 49,300 & 48,800 & \multirow[t]{3}{*}{48,200} & \multirow[t]{3}{*}{2.7} & \multirow[t]{3}{*}{$1.97 \mathrm{E}+05$} \\
\hline 2409 & $22 \mathrm{~A}$ & $1 A N-95-2$ & 51,000 & 49,300 & 50,200 & & & \\
\hline 2410 & $22 \mathrm{~A}$ & $1 \mathrm{AN}-95-3$ & 46,000 & 45,400 & 45,700 & & & \\
\hline
\end{tabular}


Table A-9. Tank 241-AN-101 Analytical Results: Phosphate.

\begin{tabular}{|c|c|c|c|c|c|c|c|c|}
\hline Labcore & pars. & $\mathrm{Grab}$ & Result & Duplicate & Mean & $\begin{array}{l}\text { Overall } \\
\text { Mean }\end{array}$ & $\begin{array}{l}\text { RSD } \\
\text { (Mean) }\end{array}$ & $\begin{array}{l}\text { Projected } \\
\text { Inventory }\end{array}$ \\
\hline Number & Number & dumber & $4 \mathrm{~g} / \mathrm{mi}$ & $4 \mathrm{~g} / \mathrm{nl}$ & $4 \mathrm{gmI}$ & $\mu \mathrm{g} / \mathrm{ml}$ & 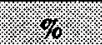 & kg. \\
\hline 2408 & $22 \mathrm{~A}$ & $1 \mathrm{AN}-95-1$ & 1,390 & 1,400 & 1,400 & \multirow[t]{3}{*}{2,120} & \multirow[t]{3}{*}{19.2} & \multirow[t]{3}{*}{8,670} \\
\hline 2409 & $22 \mathrm{~A}$ & $1 \mathrm{AN}-95-2$ & 2,880 & 2,720 & 2,800 & & & \\
\hline 2410 & $22 \mathrm{~A}$ & $1 \mathrm{AN}-95-3$ & 2,170 & 2,170 & 2,170 & & & \\
\hline
\end{tabular}

Table A-10. Tank 241-AN-101 Analytical Results: Sulfate.

\begin{tabular}{|c|c|c|c|c|c|c|c|c|}
\hline Labcore & Riket: & Grab & Resuilt & Duplicate & Mean & $\begin{array}{l}\text { Oyerall } \\
\text { Mean }\end{array}$ & $\begin{array}{l}\text { RSD } \\
\text { (Mean) }\end{array}$ & $\begin{array}{l}\text { Projected } \\
\text { Inventory }\end{array}$ \\
\hline Number & Number & Number & $t \mathrm{~g} / \mathrm{ml}$ & $19 / \mathrm{ml}$ & $1 / 8 / \mathrm{nil}$ & $48 \mathrm{mi}$ & 10 & kg \\
\hline 2408 & $22 \mathrm{~A}$ & $1 \mathrm{AN}-95-1$ & 1,580 & 1,610 & 1,600 & \multirow[t]{3}{*}{3,040} & \multirow[t]{3}{*}{24.5} & \multirow[t]{3}{*}{12,400} \\
\hline 2409 & $22 \mathrm{~A}$ & $1 \mathrm{AN}-95-2$ & 4,250 & 3,910 & 4,080 & & & \\
\hline 2410 & $22 \mathrm{~A}$ & $1 \mathrm{AN}-95-3$ & 3,460 & 3,430 & 3,440 & & & \\
\hline
\end{tabular}


Table A-11. Tank 241-AN-101 Analytical Results: Americium-241.

\begin{tabular}{|c|c|c|c|c|c|c|c|c|}
\hline Labcore & Rise & Sarab & Resilit & Duplicate & Mean & $\begin{array}{l}\text { Oyerall } \\
\text { Mean }\end{array}$ & $\begin{array}{c}\text { RSD } \\
\text { (Mean) }\end{array}$ & $\begin{array}{l}\text { Projected } \\
\text { inventory }\end{array}$ \\
\hline Number & Number & Number & $\mu \mathrm{Gm}$ & formi & a)inl & folini & .6 & . \\
\hline 2411 & $22 \mathrm{~A}$ & $1 \mathrm{AN}-95-1$ & $<1.31 \mathrm{E}-05$ & $2.28 \mathrm{E}-05$ & $1.80 \mathrm{E}-05$ & \multirow[t]{3}{*}{$5.15 \mathrm{E}-05$} & \multirow[t]{3}{*}{32.7} & \multirow[t]{3}{*}{0.211} \\
\hline 2412 & $22 \mathrm{~A}$ & $1 \mathrm{AN}-95-2$ & $6.90 \mathrm{E}-05$ & $7.28 \mathrm{E}-05$ & $7.09 \mathrm{E}-05$ & & & \\
\hline 2413 & $22 \mathrm{~A}$ & $1 \mathrm{AN}-95-3$ & $6.52 \mathrm{E}-05$ & $6.59 \mathrm{E}-05$ & $6.55 \mathrm{E}-05$ & & & \\
\hline
\end{tabular}

Table A-12. Tank 241-AN-101 Analytical Results: Cesium-134.

\begin{tabular}{|c|c|c|c|c|c|c|c|c|}
\hline Labcore & Riser & Grab & Resulf & Buplicate & Mean & $\begin{array}{l}\text { Oyerall } \\
\text { Mean }\end{array}$ & (MSD & $\begin{array}{l}\text { Projected } \\
\text { Inventory }\end{array}$ \\
\hline Yumber & Yunber & Number & HCyinl & Gint. & $.1011 \mathrm{~m}$ & 10411 & 98 & di \\
\hline 2411 & $22 \mathrm{~A}$ & $1 \mathrm{AN}-95-1$ & 0.00525 & -- & 0.00525 & \multirow[t]{3}{*}{0.00996} & \multirow[t]{3}{*}{45} & \multirow[t]{3}{*}{40.7} \\
\hline 2412 & $22 \mathrm{~A}$ & $1 \mathrm{AN}-95-2$ & 0.00574 & $\ldots$ & 0.00574 & & & \\
\hline 2413 & $22 \mathrm{~A}$ & $1 \mathrm{AN}-95-3$ & 0.0189 & -- & 0.0189 & & & \\
\hline
\end{tabular}

Table A-13. Tank 241-AN-101 Analytical Results: Cesium-137.

\begin{tabular}{|c|c|c|c|c|c|c|c|c|}
\hline Iabcore & Piser & Grab & Result & ouplicate & Mean & $\begin{array}{l}\text { Orerall } \\
\text { Vean }\end{array}$ & $\begin{array}{l}\mathrm{RSD} \\
(\mathrm{Mean})\end{array}$ & $\begin{array}{l}\text { Projected } \\
\text { Inventory }\end{array}$ \\
\hline Number & Number & Number & rovim & 49111 & horing & ovinl & $\%$ & d) \\
\hline 2411 & $22 \mathrm{~A}$ & $1 \mathrm{AN}-95-1$ & 121.5 & 121.2 & 121.3 & \multirow[t]{3}{*}{123} & \multirow[t]{3}{*}{0.6} & \multirow[t]{3}{*}{$5.03 E+05$} \\
\hline 2412 & $22 \mathrm{~A}$ & $1 A N-95-2$ & 123.0 & 123.9 & 123.5 & & & \\
\hline 2413 & $22 \mathrm{~A}$ & $1 \mathrm{AN}-95-3$ & 122.0 & 125.0 & 123.5 & & & \\
\hline
\end{tabular}



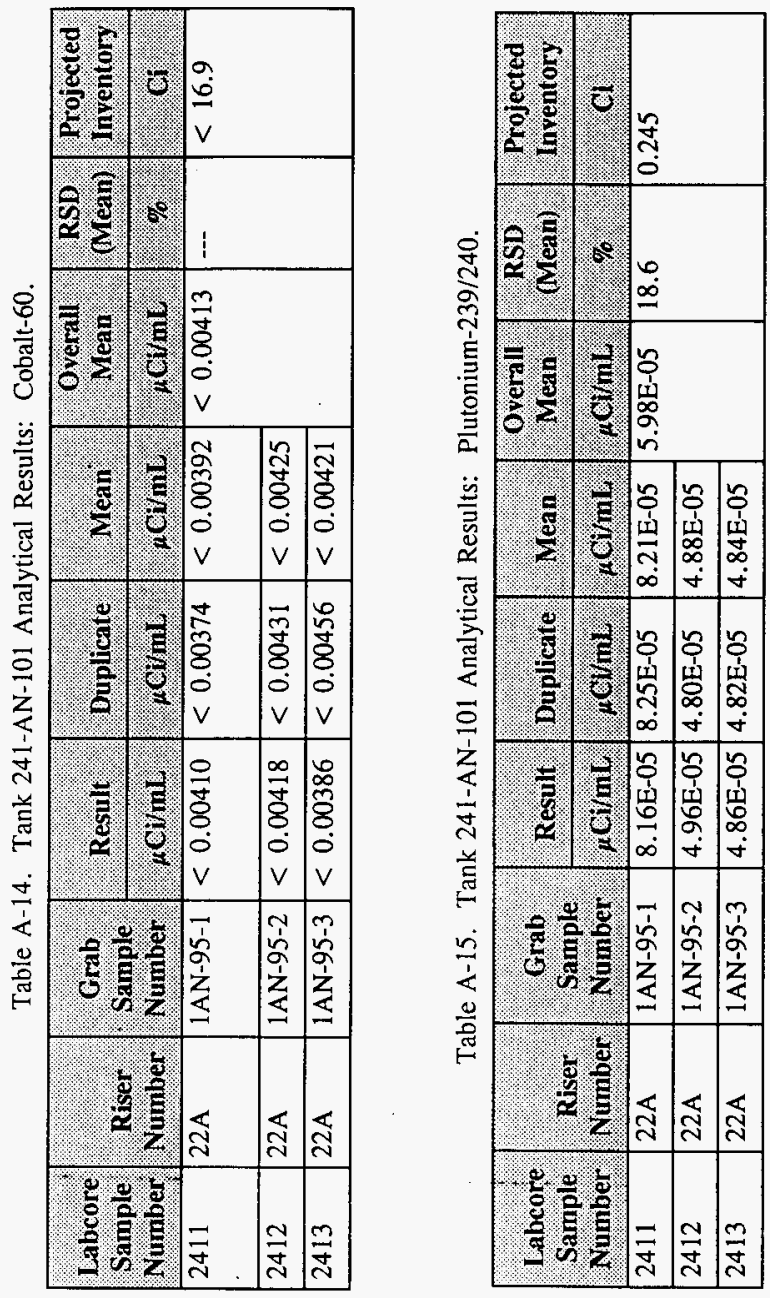
Table A-16. Tank 241-AN-101 Analytical Results: Strontium-89/90.

\begin{tabular}{|c|c|c|c|c|c|c|c|c|}
\hline Labcore & $\mathrm{P}$ (1) & Grab & Result: & Duplicate & Mean & Orerall & $\begin{array}{l}\text { RSD } \\
(\text { Mean) }\end{array}$ & $\begin{array}{l}\text { Projected } \\
\text { Inventory }\end{array}$ \\
\hline Number & Number & Number & n $1 / 1 \mathrm{mI}$ & äriml. & $101 \mathrm{mi}$ & $a 01 \mathrm{ml}$ & $.6 \%$ & \%) \\
\hline 2411 & $22 \mathrm{~A}$ & $1 \mathrm{AN}-95-1$ & 0.590 & 0.593 & 0.591 & \multirow[t]{3}{*}{0.378} & \multirow[t]{3}{*}{28.3} & \multirow[t]{3}{*}{1,550} \\
\hline 2412 & $22 \mathrm{~A}$ & $1 \mathrm{AN}-95-2$ & 0.268 & 0.259 & 0.264 & & & \\
\hline 2413 & $22 \mathrm{~A}$ & $1 \mathrm{AN}-95-3$ & 0.289 & 0.268 & 0.278 & & & \\
\hline
\end{tabular}

Table A-17. Tank 241-AN-101 Analytical Results: Total Alpha.

\begin{tabular}{|c|c|c|c|c|c|c|c|c|}
\hline \multirow{2}{*}{$\begin{array}{l}\text { Labcore } \\
\text { Sample } \\
\text { Nimber }\end{array}$} & \multirow{2}{*}{$\begin{array}{l}\text { Riser } \\
\text { Mumiber }\end{array}$} & \multirow{2}{*}{$\begin{array}{l}\text { Grab } \\
\text { Sample. } \\
\text { Mumber }\end{array}$} & Result & Duplicate & Mean & $\begin{array}{l}\text { Oyerail } \\
\text { Mean }\end{array}$ & $\begin{array}{l}\text { RSD } \\
\text { (Mean) }\end{array}$ & $\begin{array}{l}\text { Projected } \\
\text { Inventory }\end{array}$ \\
\hline & & & aCimi. & folmi. & HCinm & $.961 \mathrm{ml}$ & $\%$ & $\mathrm{Cl}$ \\
\hline 3903 & \multirow[t]{3}{*}{$22 \mathrm{~A}$} & $1 \mathrm{AN}-95-1$ & $<4.43 \mathrm{E}-04$ & $<5.95 \mathrm{E}-04$ & $<5.19 \mathrm{E}-04$ & $<0.00059$ & --- & $<2.41$ \\
\hline 3905 & & $1 \mathrm{AN}-95-2$ & $<5.43 \mathrm{E}-04$ & $<3.92 \mathrm{E}-04$ & $<4.68 \mathrm{E}-04$ & & & \\
\hline 3906 & & $1 \mathrm{AN}-95-3$ & $<7.40 \mathrm{E}-04$ & $<8.37 \mathrm{E}-04$ & $<7.89 \mathrm{E}-04$ & & & \\
\hline 3913 & \multirow[t]{3}{*}{$15 B$} & $1 \mathrm{AN}-95-4$ & $<1.01 \mathrm{E}-03$ & $<1.35 \mathrm{E}-03$ & $<1.18 \mathrm{E}-03$ & \multirow[t]{3}{*}{$<0.00147$} & & \multirow[t]{3}{*}{$<6.01$} \\
\hline 3914 & & $1 \mathrm{AN}-95-5$ & $<1.01 \mathrm{E}-03$ & $<1.86 \mathrm{E}-03$ & $<1.44 \mathrm{E}-03$ & & & \\
\hline 3915 & & $1 \mathrm{AN}-95-6$ & $<2.20 \mathrm{E}-03$ & $<1.35 \mathrm{E}-03$ & $<1.78 \mathrm{E}-03$ & & & \\
\hline
\end{tabular}


Table A-18. Tank 241-AN-101 Analytical Results: Total Inorganic Carbon.

\begin{tabular}{|c|c|c|c|c|c|c|c|c|}
\hline Labcore & Pfiser: & Grab & Result & Buplicate & Mean & $\begin{array}{l}\text { Orerall } \\
\text { Yean }\end{array}$ & $\begin{array}{l}\text { RSD } \\
\text { (Mean) }\end{array}$ & $\begin{array}{l}\text { Projected } \\
\text { Inyentory }\end{array}$ \\
\hline Nimber & Numiber & Namber & ig/mi & $18 \mathrm{r} \mathrm{mr}$ & ag/mi. & $4 \mathrm{~g} / \mathrm{ni}$ & $\%$ & $\mathrm{~kg}_{\mathrm{g}}$ \\
\hline 2408 & $22 \mathrm{~A}$ & 1AN-95-1 & 2,540 & 2,610 & 2,580 & \multirow[t]{3}{*}{2,450} & \multirow[t]{3}{*}{2.7} & \multirow[t]{3}{*}{10,000} \\
\hline 2409 & $22 \mathrm{~A}$ & $1 \mathrm{AN}-95-2$ & 2,410 & 2,390 & 2,400 & & & \\
\hline 2410 & $22 \mathrm{~A}$ & $1 \mathrm{AN}-95-3$ & 2,380 & 2,350 & 2,360 & & & \\
\hline
\end{tabular}

Table A-19. Tank 241-AN-101 Analytical Results: Total Organic Carbon.

\begin{tabular}{|c|c|c|c|c|c|c|c|c|}
\hline Labcore & Riser & Grab & Result & Duplicate & Mean & $\begin{array}{l}\text { Oyerall } \\
\text { yean }\end{array}$ & $\begin{array}{l}\text { RSD } \\
\text { (Mean) }\end{array}$ & $\begin{array}{l}\text { Projected } \\
\text { Inventory }\end{array}$ \\
\hline Niniber & Number & Number & (月g/mil. & rg/mi. & rgtmi & Hg/mi. & \%. & kg. \\
\hline 2408 & $22 \mathrm{~A}$ & 1AN-95-1 & 3,670 & 3,500 & 3,580 & \multirow[t]{3}{*}{2,630} & \multirow[t]{3}{*}{18.0} & \multirow[t]{3}{*}{10,800} \\
\hline 2409 & $22 \mathrm{~A}$ & $1 \mathrm{AN}-95-2$ & 2,150 & 2,180 & 2,160 & & & \\
\hline 2410 & $22 \mathrm{~A}$ & $1 \mathrm{AN}-95-3$ & 2,150 & 2,170 & 2,160 & & & \\
\hline
\end{tabular}


Table A-20. Tank 241-AN-101 Analytical Results: pH.

\begin{tabular}{|c|c|c|c|c|c|c|c|}
\hline $\begin{array}{l}\text { Gabcore } \\
\text { Sample } \\
\text { Number }\end{array}$ & $\begin{array}{l}\text { Riser } \\
\text { Number }\end{array}$ & $\begin{array}{l}\text { Grabs } \\
\text { Sample } \\
\text { Tumber }\end{array}$ & Resull & Buplicate & Mean & $\begin{array}{l}\text { Orenal } \\
\text { Meai }\end{array}$ & $\begin{array}{c}\text { RSD } \\
\text { (Mean) } \\
. \%\end{array}$ \\
\hline 2408 & $22 \mathrm{~A}$ & $1 \mathrm{AN}-95-1$ & 12.95 & 12.96 & 12.96 & \multirow[t]{3}{*}{13.6} & \multirow[t]{3}{*}{2.3} \\
\hline 2409 & $22 \mathrm{~A}$ & $1 \mathrm{AN}-95-2$ & 13.95 & 13.94 & 13.95 & & \\
\hline 2410 & $22 \mathrm{~A}$ & $1 \mathrm{AN}-95-3$ & 13.88 & 13.87 & 13.88 & & \\
\hline
\end{tabular}

Table A-21. Tank 241-AN-101 Analytical Results: Percent Water.

\begin{tabular}{|c|c|c|c|c|c|c|c|}
\hline Labcore Sample Number & Ristiber & Grab Sample & Result & Duplicate & Mean & $\begin{array}{l}\text { Grerall } \\
\text { Mean }\end{array}$ & $\begin{array}{l}\text { RSD } \\
(\text { Mean) }\end{array}$ \\
\hline 2408 & \multirow[t]{3}{*}{$22 \mathrm{~A}$} & 1 AN-95-1 & 66.28 & 66.11 & 66.19 & 66.0 & 0.21 \\
\hline 2409 & & $1 \mathrm{AN}-95-2$ & 66.27 & 65.72 & 66.00 & & \\
\hline 2410 & & $1 \mathrm{AN}-95-3$ & 65.96 & 65.81 & 65.88 & & \\
\hline 3913 & \multirow[t]{3}{*}{$15 B$} & $1 A N-95-4$ & 65.51 & 64.93 & 65.22 & \multirow[t]{3}{*}{65.4} & \multirow[t]{3}{*}{0.33} \\
\hline 3914 & & 1 AN-95-5 & 64.80 & 65.11 & 64.95 & & \\
\hline 3915 & & $1 \mathrm{AN}-95-6$ & 65.95 & 66.03 & 65.99 & & \\
\hline
\end{tabular}


Table A-22. Tank 241-AN-101 Analytical Results: Specific Gravity.

\begin{tabular}{|c|c|c|c|c|c|c|c|}
\hline $\begin{array}{l}\text { Labcore } \\
\text { Sample } \\
\text { Number }\end{array}$ & $\begin{array}{l}\text { Riser } \\
\text { Number }\end{array}$ & $\begin{array}{l}\text { Grab Sample } \\
\text { Number. }\end{array}$ & Result & Duplicate & Mean & $\begin{array}{l}\text { Overall } \\
\text { Mean }\end{array}$ & $\frac{\text { RSD }}{(\text { Mean) }}$ \\
\hline 2408 & \multirow[t]{3}{*}{$22 \mathrm{~A}$} & $1 \mathrm{AN}-95-1$ & 1.230 & 1.240 & 1.235 & \multirow[t]{3}{*}{1.24} & \multirow[t]{3}{*}{0.58} \\
\hline 2409 & & $1 \mathrm{AN}-95-2$ & 1.270 & 1.250 & 1.260 & & \\
\hline 2410 & & $1 \mathrm{AN}-95-3$ & 1.220 & 1.250 & 1.235 & & \\
\hline 3913 & \multirow[t]{3}{*}{$15 B$} & IAN-95-4 & 1.226 & 1.214 & 1.220 & \multirow[t]{3}{*}{1.22} & \multirow[t]{3}{*}{0.19} \\
\hline 3914 & & $1 \mathrm{AN}-95-5$ & 1.214 & 1.216 & 1.215 & & \\
\hline 3915 & & $1 \mathrm{AN}-95-6$ & 1.223 & 1.217 & 1.220 & & \\
\hline
\end{tabular}


WHC-SD-WM-ER-578 Rev. 0

This page intentionally left blank. 
WHC-SD-WM-ER-578 Rev. 0

\section{APPENDIX B}

HISTORICAL SAMPLING RESULTS 


\section{B.0 HISTORICAL SAMPLING RESULTS}

Table B-1 shows the results of a grab sampling from April 19, 1993. Three $100 \mathrm{~mL}$ supernate samples were retrieved from tank 241-AN-101 using the bottle-on-a-string sampling method (Sutey 1993). The sample locations and identifications are listed below:

Sample

Top sample

Middle sample

Bottom sample

\section{Lab Identification}

R3715

R3716

R3717

Table B-1. 1993 Sampling Results. ${ }^{1}$ (2 sheets)

\begin{tabular}{|c|c|c|c|c|}
\hline Analyte & $\begin{array}{l}\text { Sample } \\
\text { R } 3775\end{array}$ & Sample & $\begin{array}{l}\text { Sample } \\
\text { I } 374 \text { ? }\end{array}$ & $\begin{array}{l}\text { Overall } \\
\text { Mean }\end{array}$ \\
\hline Metals : & $10 \mathrm{grmi}$ & . & 1. & (g/ml \\
\hline Aluminum & 15,700 & 15,400 & 12,600 & 14,600 \\
\hline Barium & 0.119 & 0.0840 & -- & 0.102 \\
\hline Boron & 10.0 & 10.0 & 6.67 & 8.89 \\
\hline Calcium & 5.90 & 5.21 & 8.00 & 6.37 \\
\hline Chromium & 213 & 211 & 140 & 188 \\
\hline Copper & 0.312 & 0.368 & 0.964 & 0.548 \\
\hline Iron & 3.07 & 2.95 & 2.27 & 2.76 \\
\hline Lead & 15.2 & 15.0 & 11.3 & 13.8 \\
\hline Molybdenum & 31.7 & 31.0 & 20.8 & 27.8 \\
\hline Nickel & 3.06 & 3.10 & 2.35 & 2.84 \\
\hline Phosphorus & 896 & 896 & 595 & 796 \\
\hline Potassium & 3,270 & 3,250 & 2,530 & 3,020 \\
\hline Silicon & 8.46 & 8.02 & 5.14 & 7.21 \\
\hline Sodium & $1.15 \mathrm{E}+05$ & $1.13 \mathrm{E}+05$ & 84,600 & $1.04 \mathrm{E}+05$ \\
\hline Sulfur & 948 & 942 & 581 & 824 \\
\hline Tungsten & 63.3 & 63.2 & 42.8 & 56.4 \\
\hline Zinc & 2.11 & 2.64 & 1.22 & 1.99 \\
\hline$\overline{\text { Zirconium }}$ & 0.291 & 0.407 & 0.304 & 0.334 \\
\hline
\end{tabular}


WHC-SD-WM-ER-578 Rev. 0

Table B-1. 1993 Sampling Results. ${ }^{1}$ (2 sheets)

\begin{tabular}{|c|c|c|c|c|}
\hline (1) & Sample & Sample. & Sample & Oremall \\
\hline Anions & $4 \mathrm{~g} / \mathrm{mL}$ & $1 \% \mathrm{~g} \mathrm{mI}$ & 40 11. & $.897 \mathrm{~m}$ \\
\hline Hydroxide & 28,100 & 26,600 & 17,400 & 24,000 \\
\hline Nitrate & 93,600 & 89,200 & 58,600 & 80,500 \\
\hline Nitrite & 46,400 & 44,400 & 30,400 & 40,400 \\
\hline Phosphate & 2,200 & 2,280 & 1,480 & 1,990 \\
\hline Sulfate & 3,070 & 3,030 & 2,110 & 2,740 \\
\hline Chloride & 2,660 & 2,490 & 2,320 & 2,490 \\
\hline Ammonium & 86.0 & $<80.0$ & 87.4 & 84.5 \\
\hline Cyanide & 19.4 & 19.1 & 11.0 & 16.5 \\
\hline Radionuclides & $.1 \mathrm{ClmI}$. & $.1 \mathrm{QHinI}$ & $.101 \mathrm{mi}$ & $.191 \mathrm{~m}$ \\
\hline Total beta & 174 & 187 & 137 & 166 \\
\hline Total alpha & 0.114 & 0.121 & 0.0911 & 0.109 \\
\hline${ }^{241} \mathrm{Am}$ & $5.76 \mathrm{E}-04$ & $8.29 \mathrm{E}-04$ & $2.23 \mathrm{E}-04$ & $5.43 \mathrm{E}-04$ \\
\hline${ }^{137} \mathrm{Cs}$ & 120 & 123 & 93.3 & 112 \\
\hline${ }^{237} \mathrm{~Np}$ & $<5.95 \mathrm{E}-05$ & $<1.08 \mathrm{E}-04$ & $<1.08 \mathrm{E}-04$ & $9.18 \mathrm{E}-05$ \\
\hline${ }^{239 / 240} \mathrm{Pu}$ & $3.27 \mathrm{E}-05$ & $3.62 \mathrm{E}-05$ & $1.56 \mathrm{E}-05$ & $2.82 \mathrm{E}-05$ \\
\hline${ }^{90} \mathrm{Sr}$ & 0.0852 & 0.0819 & 0.100 & 0.0890 \\
\hline Carbon & $.4 \mathrm{~g} / \mathrm{mL}$ & $.4 \mathrm{~g} / \mathrm{mL}$ & $6.4 \mathrm{~g} / \mathrm{mL}$ & $.4 \mathrm{~g} / \mathrm{mL}$ \\
\hline TIC & 2,150 & 2,150 & 3,510 & 2,600 \\
\hline TOC & 2,570 & 2,140 & 1,460 & 2,060 \\
\hline \multicolumn{5}{|l|}{ Physical Properties } \\
\hline $\mathrm{SPG}(\mathrm{g} / \mathrm{mL})$ & 1.28 & 1.23 & 1.18 & 1.23 \\
\hline$\%$ Solids (wt) & 27.1 & 26.9 & 20.5 & 24.8 \\
\hline $\mathrm{DSC}$ & $\begin{array}{l}\text { No exothermic } \\
\text { reactions }\end{array}$ & $\begin{array}{l}\text { No exothermic } \\
\text { reactions }\end{array}$ & $\begin{array}{l}\text { No exothermic } \\
\text { reactions }\end{array}$ & $\cdots$ \\
\hline TGA $\left(\% \mathrm{H}_{2} \mathrm{O}\right)$ & 71.8 & 71.7 & 81.0 & 74.8 \\
\hline $\mathrm{pH}$ & 13.8 & 13.7 & 13.6 & 13.7 \\
\hline
\end{tabular}

Note:

${ }^{1}$ Sutey (1993) 
WHC-SD-WM-ER-578 Rev. 0

This page intentionally left blank. 


\section{DISTRIBUTION SHEET}

\begin{tabular}{|c|c|c|c|c|c|}
\hline \multirow{2}{*}{$\begin{array}{l}\text { To } \\
\text { Distribution }\end{array}$} & \multirow{2}{*}{\multicolumn{3}{|c|}{$\begin{array}{l}\text { Data Assessment and } \\
\text { Interpretation }\end{array}$}} & \multicolumn{2}{|l|}{ Page 3 of 4} \\
\hline & & & & \multicolumn{2}{|c|}{ Date $\quad 07 / 22 / 96$} \\
\hline \multicolumn{6}{|l|}{ Project Title/Work Order } \\
\hline \multicolumn{6}{|c|}{$\begin{array}{l}\text { Tank Characterization Report for Double-She11 Tank 241-AN-101, } \\
\text { WHC-SD-WM-ER-578, Rev. } 0\end{array}$} \\
\hline Name & MSIN & $\begin{array}{c}\text { Text } \\
\text { With All } \\
\text { Attach. }\end{array}$ & Text Only & $\begin{array}{l}\text { Attach./ } \\
\text { Appendix } \\
\text { Only } \\
\end{array}$ & $\begin{array}{l}\text { EDT/ECN } \\
\text { Only }\end{array}$ \\
\hline
\end{tabular}

ONSITE

Department of Eneray - Richland Operations

J. F. Thompson

W. S. Liou

N. W. Willis

$\begin{array}{ll}57-54 & x \\ 57-54 & x \\ 57-54 & x\end{array}$

ICF-Kaiser Hanford Company

R. L. Newell

S3-09

$x$

Pacific Northwest Laboratory

N. G. Colton

J. R. Gormsen

K3-75 $\quad x$

S. A. Hartley

J. G. Hill

G. J. Lumetta

A. F. Noonan

$\mathrm{K} 7-28$

$x$

$\mathrm{K} 5-12$

K7-94

P7-25

K9-81

$x$
$x$
$x$

Westinghouse Hanford Company

H. Babad

57-14 $\quad x$

D. A. Barnes

C. J. Benar

G. R. Bloom

W. L. Cowley

L. A. Diaz

G. L. Dunford

E. J. Eberlein

D. B. Engelman

J. S. Garfield

J. D. Gubersk i

D. L. Herting

D. C. Hetzer

G. Jansen

G. D. Johnson

T. J. Kelley

N. W. Kirch

M. J. Kupfer

J. E. Meacham

R1-80 $\quad X$

R2-12 $\quad x$

H5-61 $X$

A3-37 $x$

T6-06 $x$

S7 $-81 \quad x$

R2-12

$x$

$\begin{array}{rr}R 1-49 & X \\ H 5-49 & X\end{array}$

R1-51

T6-09

56-31

H6-33

57-15

S7-21

R2-11

H5- 49

S7-15

$$
x
$$




\section{DISTRIBUTION SHEET}

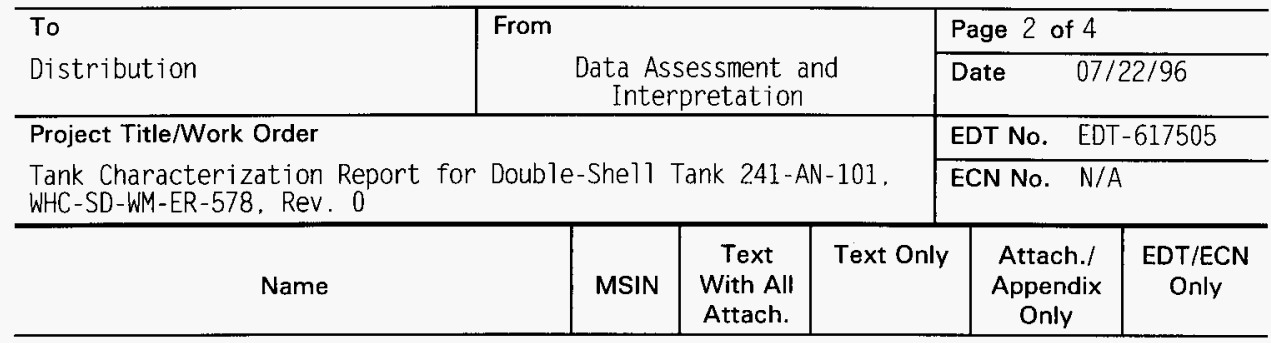

SAIC

20300 Century Boulevard. Suite 200-B

Germantown. MD 20874

H. Sutter

$x$

555 Quince Orchard Rd., Suite 500

Gaithersburg, MD 20878

P. Szerszen

$X$

Los Alamos Laboratory

CST-14 MS-J586

P. 0 . Box 1663

Los Alamos, NM 87545

S. F. Agnew (4)

$x$

Los Alamos Technical Associates

T. T. Tran

B1-44 X

Ogden Environmental

101 East Wellsian Way

Richland. WA 99352

R. J. Anema

$x$

CH2M Hill

P. O. Box 91500

Bellevue, WA 98009-2050

M. McAfee

$x$

Tank Advisory Panel

102 Windham Road

Oak Ridge. TN 37830

D. O. Campbe11 
DISTRIBUTION SHEET

\begin{tabular}{|c|c|c|c|c|c|}
\hline \multirow{2}{*}{$\begin{array}{l}\text { To } \\
\text { Distribution }\end{array}$} & \multirow{2}{*}{\multicolumn{3}{|c|}{$\begin{array}{l}\text { Data Assessment and } \\
\text { Interpretation }\end{array}$}} & \multicolumn{2}{|l|}{ Page 1 of 4} \\
\hline & & & & \multicolumn{2}{|c|}{ Date $\quad 07 / 22 / 96$} \\
\hline \multirow{2}{*}{\multicolumn{4}{|c|}{$\begin{array}{l}\text { Project Title/Work Order } \\
\text { Tank Characterization Report for Double-She17 Tank 241-AN-101, } \\
\text { WHC-SD-WM-ER-578, Rev. } 0\end{array}$}} & \multicolumn{2}{|c|}{ EDT No. $\quad$ EDT-617505 } \\
\hline & & & & \multicolumn{2}{|c|}{ ECN No. N/A } \\
\hline Name & MSIN & $\begin{array}{l}\text { Text } \\
\text { With All } \\
\text { Attach. }\end{array}$ & Text Only & $\begin{array}{l}\text { Attach./ } \\
\text { Appendix } \\
\text { Only }\end{array}$ & $\begin{array}{l}\text { EDT/ECN } \\
\text { Only }\end{array}$ \\
\hline
\end{tabular}

\section{OFFSITE}

Sandia National Laboratory

P. O. Box 5800

MS-0744, Dept. 6404

Albuquerque. NM 87815

D. Powers

Nuclear Consulting Services Inc.

P. 0. Box 29151

Columbus. $\mathrm{OH}$ 43229-01051

J. L. Kovach

$x$

Chemical Reaction Sub-TAP

P.0. Box 271

Lindsborg, KS 67456

B. C. Hudson

$x$

Tank Characterization Panel

Senior Technical Consultant

Contech

7309 Indian School Road

Albuquerque, NM 87110

J. Arvisu

$x$

U. S. Department of Enerqy - Headquarters

Office of Environmental Restoration and Waste Management EM-563

12800 Middlebrook Road

Germantown. MD 20874

J. A. Poppitti

$x$

Jacobs Enqineering Group

B5-36

$x$ 


\begin{tabular}{|c|c|c|c|c|c|}
\hline \multicolumn{6}{|c|}{ DISTRIBUTION SHEET } \\
\hline To & \multirow{2}{*}{\multicolumn{3}{|c|}{ From }} & \multicolumn{2}{|l|}{ Page 4 of 4} \\
\hline Distribution & & & & Date & $2 / 96$ \\
\hline \multicolumn{4}{|l|}{ Project Title/Work Order } & \multicolumn{2}{|c|}{ EDT No. EDT-617505 } \\
\hline \multicolumn{4}{|c|}{$\begin{array}{l}\text { Tank Characterization Report for Double-She } 11 \text { Tank 241-AN-101, } \\
\text { WHC-SD-WM-ER-578, Rev. 0 }\end{array}$} & \multicolumn{2}{|c|}{ ECN No. N/A } \\
\hline Name & MSIN & $\begin{array}{c}\text { Text } \\
\text { With All } \\
\text { Attach. }\end{array}$ & Text Only & $\begin{array}{l}\text { Attach./ } \\
\text { Appendix } \\
\text { Only }\end{array}$ & $\begin{array}{l}\text { EDT/ECN } \\
\text { Only }\end{array}$ \\
\hline
\end{tabular}

Westinghouse Hanford Company continued

W. C. Miller

C. T. Narquis

D. E. Place

D. A. Reynolds

L. M. Sasaki (2)

L. W. Shelton. Jr.

B. C. Simpson

G. L. Troyer

L. R. Webb

K. A. White

FEIC (Tank Fam Information Center)

Central Files

EDMC

ERC (Environmental Resource Center)

R1 -56

T6- 16

H5-27

R2- 11

R2-12

H5 -49

R2 -12

T6-50

T6-06

S5-13

RI $=20$

A3-88

H6-08

R1-51

$x$
$x$
$x$
$x$
$x$
$x$
$x$
$x$
$x$
$x$
$x$
$x$
$x$
$x$

NO LONGER

TCRC (10)

R2-12 X

